\title{
Impact of structured education on glucose control and hypoglycaemia in Type-2 diabetes: a systematic review of randomized controlled trials
}

\section{Ernest Yorke and Yacoba Atiase}

Ghana Med J 2018; 52(1): 41-60 DOI: http://dx.doi.org/10.4314/gmj.v52i1.8

\begin{abstract}
Department of Medicine \& Therapeutics, School of Medicine and Dentistry, College of Health Sciences, University of Ghana, Accra, Ghana
\end{abstract}

Corresponding author: Dr Ernest Yorke

E-mail: pavlovium@yahoo.com

Conflict of interest: None declared

\section{SUMMARY}

Evidence for the use of structured education in diabetes management is accumulating and has shown positive influence in the management of Type-2 diabetes.

Objective: To assess the impact of structured education on glucose control and hypoglycaemia in the management of Type-2 diabetes.

Methods: A systematic review was done using Medline via Ovid and EMBASE databases of published English literature between 1980 and 2014. Included studies were randomized control trials that assessed the impact of structured education on glucose control and hypoglycaemia.

Results: Out of the 12,086 full text articles were identified, 36 full text articles were finally considered for this review after applying both inclusion and exclusion criteria, of which 34 were exclusively on the effect of structured diabetes education on glucose control whilst 2 were studies on the effects of structured diabetes education on glucose control and hypoglycaemia. Majority of the studies included a predominant Caucasian population. There was heterogeneity in the included studies such as intervention methods and intensity as well as follow up periods. Group based education was preferred over individual education by most studies. Overall, most of the studies showed a significant positive effect on glycaemic control compared with control groups. One study showed a significant impact of structured education on hypoglycaemia.

Conclusion: Structured education has positive impact on glucose control and hypoglycaemia in Type-2 diabetes and must be incorporated in routine care.

Funding: The study was funded by the authors

Keywords: Structured education, Type-2 diabetes, glucose control, hypoglycaemia, effectiveness

\section{INTRODUCTION}

The global incidence of diabetes is increasing with the highest increases expected to be seen in sub-Saharan Africa. ${ }^{1}$ Non-pharmacological measures are important strategies in the management of diabetes mellitus, of which structured patient education remains a backbone ${ }^{2-}$ 4

Like many chronic diseases, the patient must be taught to take absolute control of his or her own condition to be able to meet the daily challenges of the disease. ${ }^{2-4}$ Structured Education in Diabetes Management (SEDM) helps ensure that the adaptation by the client is interwoven seamlessly with minimal disruption as possible to his/her daily routines. It is also aimed at minimising the psychological and emotional burden that the disease brings to the patient, family as well as carers. ${ }^{2-5}$ The set of new coping skills focuses on dealing with both acute and chronic complications., 3,6
Whilst diabetes education has always been part of diabetes management since the 1930 's ${ }^{7,8}$, it became more structured only a couple of decades ago and evidence for its effectiveness is gradually accumulating. Consequently, the content, structure and mode of delivery of such SEDM is constantly been reviewed with new evidence from research outcomes. ${ }^{9}$ An evidenced based curriculum will therefore also provide a basis for reimbursement of claims to a very great extent. Any structured education course content should be flexible, comprehensive, relevant to client's clinical and psychological needs and adaptable to a client's educational and cultural background. ${ }^{10}$ SEDM has evolved over the decades as a key component that is recommended in the management of Type- 2 diabetes. ${ }^{2-6}$ 
The evidence for the usefulness of SEDM has been growing over the years. These include positive impact on self-confidence, understanding of the disease, selfmanagement, dealing with acute complications, impact on glycaemic control, chronic complications as well as cost-effectiveness. ${ }^{4,11}$ Whilst earlier studies did not show clear benefits on glycaemic control, probably because of study designs and methodology, more recent randomized control trials and meta-analyses have pointed in a positive direction in terms of glycaemic control, psychological and cognitive impact, self-care measures and cost-effectiveness. ${ }^{4,}{ }^{12-17}$ The landmark trials of Diabetes Control and Complications Trial (DCCT) and United Kingdom Prospective Diabetes Study (UKPDS) targeted intensive glycaemic control and employed selfeducation as a key strategy in achieving their endpoints. ${ }^{18,19}$ Unfortunately, despite this growing evidence on the usefulness of SEDM, many caregivers all over the world, especially in the developing world, do not offer SEDM. It is also not reimbursed in many places that have instituted it. ${ }^{20}$

This report specifically seeks to find out the current evidence for the effectiveness of SEDM on glucose control and hypoglycaemia. It is hoped this result from this review would add to the evidence of the effectiveness of SEDM in Type-2 diabetes; and serve to encourage more caregivers to incorporate SEDM in their routine care.

\section{METHODS}

This systematic review focused on literature search from the period January 1980 to September 2014 of published randomized controlled trails in English language using MEDLINE via Ovid and EMBASE databases. The review process followed the PRISMA (Preferred Reporting Items for systematic Reviews and Meta-analyses) guidelines. ${ }^{21}$

Inclusion criteria included randomized control trials that assessed the impact of SEDM on glycaemic control (HBA1c) and hypoglycaemia in Type-2 diabetes. Included studies must have participants aged 18 years and above and published between January 1980 and September 2014. The exclusion criteria included studies published in a language other than English, among subjects with other types of diabetes including Type-1 diabetes, published before January 1980 and also among diabetes subjects less than 18 years old.

\section{Search Strategy}

A structured search of medical literature published in English Language between January 1980 and September 2014 was conducted using the Cardiff University electronic databases MEDLINE via Ovid and EMBASE.
The medical subject headings (MeSH) Diabetes Mellitus and Diabetes Education were searched and combined. Selected and included sub-headings from the search were Type-2 diabetes, diabetes complications, patient education, structured education, health education and self-care. The results of this combination were systematically combined with:

1. Glucose control (with selected sub-headings such as Type-2 diabetes, blood glucose, diabetes mellitus, haemoglobin A, haemoglobin a1C, glycated haemoglobin, glycosylated haemoglobin, hypoglycaemic agents, adults) and

2. Hypoglycaemia (with selected sub-headings such as low blood glucose, blood, complications, diagnosis, classification, epidemiology, history, mortality, prevention, control, therapy and physiopathology) respectively. Relevant references of searched articles were also evaluated for inclusion if not found in the electronic database.

\section{Study Selection}

All the results of the search were subsequently saved and initial screening done by reading the title of papers to include or exclude them. Papers that were found not to be relevant to the subject of the review were excluded at this stage. Subsequently, abstracts of remaining papers were read to exclude irrelevant ones. The remaining papers were saved for full text consideration. Papers that gave only access to abstracts were also excluded, as they did not provide sufficient information to assess the validity of the study. Manual search of the references of saved full text articles was done to identify and include any relevant paper that may have been missed during the electronic search. Only randomized control trials in subjects with Type- 2 diabetes were selected, as they tend to support maximum validity and causal inferences.

\section{Data extraction}

Selected studies were divided into two main groups. Group 1 were randomized control trials that assessed the impact of structured diabetes education on glycaemic/glucose control, whilst Group 2 was randomized control trials that assessed the impact on hypoglycaemia. The type of structured education was irrespective of the provider delivering it, whether individual or group based and could involve any medium including oral, written, video, computer, multimedia messaging or Internet based. Consideration of studies did not also include duration of disease, severity of diabetes, presence of other co-morbidities, frequency or intensity as well as duration of interventions. 


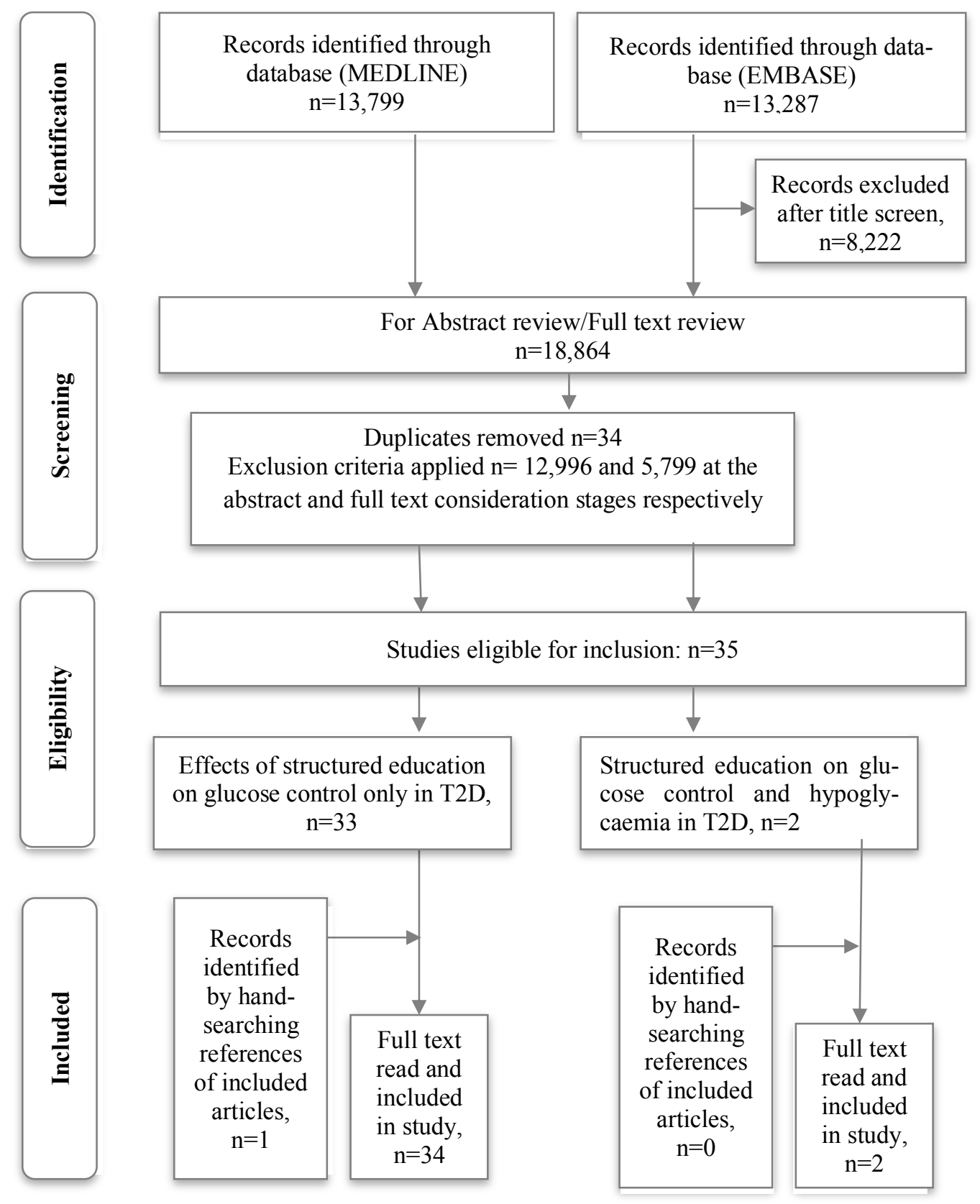

Figure 1 Flow diagram of study selection based on the PRISMA 2009 guidelines

If multiple interventions were used, studies were included only if the educational component could be examined separately.
The information and characteristics from the included studies was summarized in a tabular form (Appendix 1 $\& 2)$. 
Included variables were name of first author, publication year, demographic characteristics, country of study, methods (study design, sample size, participant selection), and results (outcome measures and conclusions). If more than one pre-defined follow up intervals were used, only the last follow up was considered in the analyses. The main outcomes measures were:

- To ascertain the change in glucose control (HBA1c) at baseline compared with the end of the intervention period.

- To ascertain the change in episodes of hypoglycaemia at baseline compared with the end of the intervention period.

Studies that assessed both of these outcomes were included if the impact could be assessed separately.

\section{Data synthesis and analysis}

Using the PRISMA guidelines as a guide ${ }^{21}$, the results of the search were summarized into a flow chart (Figure 1). Also, the selected studies were summarized and the various variables indicated above set up in a tabular form (refer Appendix $1 \& 2$ ).

Quality assessment of the studies: Strength of evidence and Risk of bias

Individual studies were assessed for quality based on the Cochrane recommendations and methodology using the Grading of Recommendations, Assessment, Development and Evaluation (GRADE) profiler software version 3.6.1.22 The study design and internal validity were also considered. Internal validity was measured by risk of bias including selection, performance, attrition and detection biases. Other considered significant contributors to the quality of studies were inconsistencies, indirectness and imprecision. ${ }^{23,}{ }^{24}$ The studies were graded as high, moderate, low or very low in quality.

\section{RESULTS}

Searching through the English Literature, 36 full text articles were finally considered for this review, of which 34 were exclusively on the effect of structured diabetes education on glucose control whilst two were studies on the effects of structured diabetes education on both glucose control and hypoglycaemia. In all, 27,086 full text articles were identified from both the MEDLINE via Ovid and EMBASE databases with 13,799 from the former and 13,287 from the latter.

After titles were screened, 8,222 were excluded leaving 18,864 papers for abstract review and of which 12, 996 were considered ineligible and 34 as duplicates leaving a total of 5,834 for full text consideration. 35 articles from full text review and 1 from searching references of articles eventually met the inclusion criteria and were considered for the systematic review as shown by Fig- ure 1. Each author was responsible for extracting data from half of the selected articles and results were exchanged and vetted by the other person. Discrepancies were resolved through consensus.

\section{Effect of Structured Education on Glucose control and Hypoglycaemia}

Thirty-six full-text articles altogether satisfied both the inclusion and exclusion criteria and are summarized in Appendix $1 \& 2$. Seventeen of the studies (17/36) were of European origin with a predominant Caucasian population; nine studies were from Unites States of America (USA), 7 from Asia and the rest from other parts of the world (Appendix 1). In total, 11,884 subjects were involved in all the studies with an age range of 18-90 years and majority of them had Type-2 diabetes for over 12 months. One study by Davies et al ${ }^{13}$ involved patients newly diagnosed with Type-2 diabetes. Subjects were mostly recruited from General practices and community clinics (Appendix 1).

The period of the intervention ranged from a few days up to several months, whilst the follow up period varied from weeks to up to four years. The intervention and mode of delivery were varied. Most of the studies used group-based education, whilst a few were one-on-one. The instructors were mainly diabetes nurse educators trained to deliver those specific interventions whilst a few studies involved peer educators as well as lay health educators (Appendix 1). The medium of instruction and education were very varied and these included talks, telephone, short messaging service (SMS), Internet based, audio-visuals and printed materials as well as home visits. Again, in most of the studies, the educational methods were interactive, and participants were actively involved in the learning process by way of oral or written feedback, text messaging, videos, discussions and role plays. Most of the control methods were either Usual Care or Waiting list control methods (where control subjects were given the intervention methods at study end or assigned time after the study had begun).

Overall, most of the studies (20 out of 36) showed a significant positive effect on glycaemic control compared with control groups (Appendix 1). The rest of the studies showed no difference after correcting for confounders, though on their own, despite the lack this significant difference, a lot of the intervention groups showed a tendency towards improved glycaemic controls (Appendix 1). Though studies 2,3,23 25-27, Appendix 1, showed significant differences in glycaemic outcomes between the intervention and control groups in the short term (6-8 months), at the end of the follow up periods (12-18 months), there was no difference between the two groups. 
With respect to the studies on hypoglycaemia, a total of 1511 subjects were involved in the 2 studies drawn from the USA and China. In the first study ${ }^{28}$, Study 1, Appendix 2, the intervention lasted six weeks involving the use of a community-based, peer-led diabetes selfmanagement programme. After six months, there was a significant improvement in the symptoms of hypoglycaemia compared to controls. The second study ${ }^{29}$, Study 2, Appendix 2, involved insulin treated Type-2 diabetes patients who had been on two or more oral agents ${ }^{29}$. After 16 weeks of follow up, there was no difference in overall incidence of hypoglycaemic events in the two groups (education and control groups were 2.28 and 1.75 episodes per person-year, respectively $(P>0.05)$.

\section{DISCUSSION}

Overall, majority of the studies demonstrated a significant impact of SEDM on glucose control. With respect to hypoglycaemia, the study by Lorig et $\mathrm{al}^{28}$ (Appendix 2) showed a significant positive impact of SEDM on hypoglycaemia whilst the second by Guo et $\mathrm{al}^{29}$ (Appendix 2), did not show any significant difference between the control and intervention groups at the end of the follow up period. Apart from glucose control and hypoglycaemia, many studies also assessed the impact of SEDM on lifestyle practices; self-care (diet, physical exercise, self-monitoring of blood glucose (SMBG), knowledge, psychological state, weight loss, blood pressure, lipid control etc. These other aspects were not considered under this review.

\section{Structured Educational Methods}

Professionals with varied backgrounds delivered the interventions in the various studies. They were mainly nurse educators and practice nurses, whilst others included community health workers, dieticians, trained pharmacists, lay health as well as peer educators. In one study (Appendix 1), an Endocrinologist was involved. ${ }^{30}$ The course content, methods employed and the duration of training employed in preparing these professionals to deliver the intervention also differed considerably, and were not even stated in some of the studies. The actual intervention methods employed, duration of intervention, frequency of reviews, overall contact time and follow up periods also varied considerably from weeks to several months. The study by Trento et al ${ }^{31}$ had a total follow up period of 4 years.

The objective of most of the interventions was to promote self-management of diabetes based on the 'theory of empowerment', which emphasizes that the acquisition of knowledge does not automatically lead to behaviour change. ${ }^{32}$ Rather, by employing motivational and goal-directed skill teaching (which may be practical, physical, conceptual, social, emotional or personal), greater and longer lasting effects are likely to be achieved and sustained. ${ }^{32}$ All these differences in the methodology are likely to affect outcomes, their interpretation and generalizability.

\section{Structured Diabetes Management Education on Glucose control}

Majority of the studies (55\%) summarized in Appendix $1^{25,29,31,33-49}$ demonstrated a positive significant effect of the various forms of SEDM on glycaemic control compared to controls. Within this group, most of the interventions were group based; however individual intervention methods were used in seven of the studies. ${ }^{35,39,41,42} 4548,50$ Early studies on the effect of diabetes education on glycaemic control were inconsistent; however later meta-analyses on this subject have demonstrated a tendency towards improved glycaemic control $^{5,12,16}$, especially when the use of glycosylated haemoglobin (HbA1c) became widely available. Good glycaemic control if achieved early in the course of diabetes delays the onset and progression of microvascular complications. ${ }^{18,19}$ In the landmark DCCT study, patient training and education about diabetes and its treatment as well as supporting their self-management efforts to improve their glycaemic control was keenly emphasized throughout the duration of the trial. ${ }^{19}$ Core to this approach was the use of multidisciplinary team consisting of at least one healthcare practitioner or educator such as a registered nurse or nutritionist. ${ }^{19}$ The findings of both the DCCT and Nurse case management study by Aubert et al ${ }^{51}$ suggest that maximal effects of diabetes education are achieved when it is interwoven in routine diabetes care. The latter was a randomized controlled trial that used a 12-hour education programme. The combined medical and education case management approach led to greater improvements in glycaemic control (HbA1c 1.1\%) compared with controls who received usual care. ${ }^{51}$

A gradual shift from the traditional didactic approach to education in the 1970's to 1980's to group empowerment based education in the 1990's has being recognized over the years. ${ }^{52}$ Some of the advantages of group based education include increased cost-effectiveness especially in the setting of limited resources; increased overall contact time and sharing and learning from experiences of individual members of the group. ${ }^{53}$ The effectiveness of group based structured diabetes education was demonstrated by Deakin et $\mathrm{al}^{49}$ in a Cochrane review in 2005 which included 11 studies with 1532 participants.

In a meta-analysis, there was a significant reduction in $\mathrm{HbA1c}$, fasting blood glucose and body weight among the intervention group. ${ }^{49}$ 


\section{Original Article}

Also, there was a reduced need for medications and an improvement in diabetes knowledge. ${ }^{49}$

Only one study by Davies et al from the UK ${ }^{13}$, had participant Type-2 diabetes patients who were newly diagnosed; the rest of the studies had subjects with established Type- 2 diabetes for usually over 1 year (Appendix 1). In this self-management for ongoing and newly diagnosed (DESMOND) programme for people with newly diagnosed Type-2 diabetes, at the end of the intervention, $\mathrm{HbAlc}$ levels at 12 months had decreased by $1.49 \%$ in the intervention group compared with $1.21 \%$ in the control group. After adjusting for baseline and cluster, the difference was not significant: $0.05 \%(95 \%$ confidence interval $-0.10 \%$ to $0.20 \%$ ). The intervention group also showed a greater weight loss: $-2.98 \mathrm{~kg}(95 \%$ confidence interval -3.54 to -2.41 ) compared with 1.86 $\mathrm{kg}(-2.44$ to -1.28$), \mathrm{P}=0.027$ at 12 months. ${ }^{13}$

It is noteworthy, that some of the studies that involved minority populations were adapted to make it culturally acceptable and in some instances, delivered in a language better understood by the minority population. $33,35,36,41,43,44$ Culturally appropriate and contextrelevant interventions have been found to delay the onset of diabetes and prevent its complications. ${ }^{54}$ The Healthcare Commission, UK, in $2007^{55}$, reported that persons of Black and ethnic minority populations considered the need for structured education a priority and were prepared to attend one. However, only $11 \%$ of people had ever been offered one. If adaptations are made to these education programmes to suit these minority ethnic populations (who incidentally have the greatest burden of Type-2 diabetes), the inequality in access is likely to be improved and also make the education more cost-effective. ${ }^{55}$

The studies by Samuel-Hodge et $\mathrm{al}^{56}$, Cooper at $\mathrm{al}^{26}$ and Goudswaard et $\mathrm{al}^{27}$ did not show a significant difference in glycaemic at the end of the follow up period (12-18 months); however, interim analyses (6-8 months) did demonstrate statistically significant improvement in glucose control the intervention group compared to controls. Diabetes is a life-long disease, and like many chronic illnesses, the patient must be empowered to take control of their condition on a long-term basis. The diminishing effects of some of these interventions in diabetes with longer follow-up intervals have been demonstrated in the past. ${ }^{57}$ Contact time was the only significant predictor of improved glycaemic control in a previous meta-analysis on structured diabetes selfmanagement education by Norris et al ${ }^{58}$ in 2002.
Also, a large meta-analysis showed that the effect of SEDM are not sustained beyond 4 months ${ }^{59}$, however another study by Padgett et al ${ }^{5}$ found that dietary education had the largest effect size on glucose control with relaxation techniques being the weakest. In an Italian study by Trento et $\mathrm{al}^{31}, 815$ non-insulin-treated T2D patients with more than one year diabetes duration were randomized into intervention and control groups, with the control group receiving seven one-hour educational sessions over two years and repeated. This form of education (REMEO) involved mainly group work, handson activities, problem solving, real-life simulations, and role-playing. Total follow up was 4 years. The control group received usual care. At study end of the four years, there was lower $\mathrm{HbAlc}$ in the intervention group ( $7.3 \pm 0.9$ vs. $8.8 \pm 1.2 \%)$ with an adjusted mean difference of -1.49 (CI, $-1.63,-1.34), \mathrm{p}<0.001$; and improvements in other psychological and metabolic parameters. Sperl-Hillen et al ${ }^{60}$ in their study, assessed whether diabetes self-management education for patients would result sustained outcomes . The randomized controlled trial had over 600 adult Type- 2 diabetes involved with $\mathrm{HbA} 1 \mathrm{c}>7 \%$; the conventional individual education (but not group education) had significant improvements in self-efficacy and reduced diabetes distress compared with usual care. ${ }^{17}$ However, it was observed that there were improvements in $\mathrm{HbAlc}$, nutrition, and physical activity in the short-term but these gains were not sustained. The authors concluded that patients with Type- 2 diabetes would require ongoing reinforcement to achieve lasting behavioural change and glucose control. ${ }^{60}$

One could infer that, to achieve clinically meaningful effects, there should be adequate time spent with clients to maintain improved glycaemic control. This would require a lot of resources, both human and material to implement and sustain such interventions. With meagre healthcare budgets around the world especially in developing countries, this would indeed prove a herculean task. Compounding this, is the reluctance of insurance companies to re-imburse costs of diabetes education ${ }^{20}$, and therefore more advocacy and evidence is needed to convince such companies to change their attitudes.

Associated with such interventions is a high attrition rate. ${ }^{58}$ In the ROMEO study described above ${ }^{31}$, only 592 participants out of the 815 (72.6\%) who started, completed the trial at the end of the 4 years. It takes a lot of resources, careful planning and execution to sustain interest among the subjects to achieve desired outcomes. $^{53}$ 
In the real world, the ability to sustain this interest among patients is even more crucial because the prevailing conditions are difficult as well as different from the 'ideal' created by the experimental conditions. ${ }^{58}$

\section{Structured Diabetes Management Education on Hy- poglycaemia}

The first of the studies that assessed the impact of SEDM on hypoglycaemia was by Lorig et al from the USA. ${ }^{28}$ This was a peer-led diabetes self-management programme for participants with Type-2 diabetes from churches and senior centres. The programme was highly interactive with emphasis placed on planning and problem solving by incorporating skill building, goals setting, reinforcement and self-efficacy. At six months, intervention participants did not demonstrate significant improvements in A1C as compared with controls $(p>0.05)$; however there were significant improvements in symptoms of hypoglycaemia, depression, communication with physicians, healthy eating, and reading food labels at 6 months $(P<0.01) .{ }^{28}$ The second study on hypoglycaemia from this review was by Guo et al from China. ${ }^{29}$ Nurses delivered the SEDM to insulin treated Type-2 diabetes patients. At 6 weeks follow up; there was no difference in the overall incidence of hypoglycaemic events in intervention groups compared with controls $(\mathrm{p}>0.05)$.

Like most systematic reviews and randomized controlled trials in the past ${ }^{16,57}$, the impact of SEDM on hypoglycaemia have not been thoroughly and rigorously assessed. It is a truism that generally, the incidence and severity tend to be more in Type- 1 diabetes than in Type-2. However, among Type-2 patients those on insulin therapy, sulphonylyurea, old age group, long duration of diabetes, some concomitant medications, renal impairment, hypoglycaemia unawareness, and cognitive dysfunction among others are some of the risk factors for hypoglycaemia. On the contrary, whilst the lack of rigorous literature may give the false impression that hypoglycaemia in Type-2 diabetes is without risks, there are possible negative effects. These include short-term effects of enhanced counter regulatory hormonal effects and neuroglycopaenia such as irritability, confusion, and in severe cases stupor, coma, and even death. ${ }^{61}$ Long term effects of hypoglycaemia may include reduced working capacity, weight gain, loss of self-confidence with reduced quality of life, and increased risk for cardiovascular diseases. ${ }^{61}$ It is obvious that these are not without costs to the patient, society at large and the healthcare system. SEDM therefore becomes a useful tool for educating both patients and healthcare professionals to improve their awareness, recognition and management of hypoglycaemia. The appropriate use of glucose lowering medications with lower risk of hypoglycaemia even become more paramount. ${ }^{61}$

Some limitations were noted. The search was based on English-language literature and also not from all available search engines and there might have excluded some possible useful studies. However, this former potential effect above might be limited according to Moher et al ${ }^{62}$ who found out that only $2 \%$ overestimated treatment effect occur in language-inclusive studies. There may be other important studies with different study designs on this subject, which may have been excluded. There were internal validity concerns with respect to selection, performance, attrition, and detection biases. The greatest concern was with concealment of allocation and blinding, with are difficult to ensure in this type of study design and subjects.

The review concentrated on the effect of SEDM on glucose control and hypoglycaemia, excluding other important outcomes like self-care behaviours, attitudes and psychological effects; which frequently have important influences on the overall outcomes in the life of Type- 2 diabetes patients. ${ }^{58}$

\section{CONCLUSION}

This review has once again brought to the fore, the importance of SEDM as an integral part in the management of Type-2 diabetes. It showed an overall positive impact of SEDM on both glucose control and hypoglycaemia.

Included studies were randomized control trials which increases the acceptability and applicability of the findings of this review..$^{23}$ Most of the studies used group based interventions which are likely to be cost-effective and offers greater opportunity for people to share experiences and behaviour change. ${ }^{32}$ What remains to be seen is whether these positive effects from SEDM are maintained in the long term.

\section{Future research}

It is hoped future research on the effectiveness of SEDM in Type-2 diabetes should be designed to evaluate the long-lasting effect of SEDM and whether initial short-term improvements in metabolic control, psychological attributes, coping mechanisms and self-care behaviours are sustained.

There should be greater efforts made to improve allocation concealment and blinding, a situation, which was difficult to achieve in many of the studies in this review. 


\section{REFERENCES}

1. Aguiree F, Brown A, Cho NH, Dahlquist G, Dodd S, Dunning T, et al. IDF diabetes atlas. 2013. Available www.idf.org/sites/default/files/EN_6E_Atlas_Full_0 .pd. Accessed on 12/03/2015.

2. Crabtree MK. Performance of diabetic self-care predicted by self-efficacy. Diabetes 1987;36[Suppl 1]:32A.

3. Type 2 diabetes: the management of type 2 diabetes. NICE guidelines (CG87), May 2009. Available at www.nice.org.uk/CG87. Accessed 12/09/15.

4. Gillett M, Dallosso HM, Dixon S, Brennan A, Carey ME, Campbell MJ, et al. Delivering the diabetes education and self management for ongoing and newly diagnosed (DESMOND) programme for people with newly diagnosed type 2 diabetes: cost effectiveness analysis. Bmj. 2010;20(341).

5. Padgett D, Mumford E, Hynes M, Carter R. Metaanalysis of the effects of educational and psychosocial interventions on management of diabetes mellitus. J Clin Epidemiol. 1988;41(10):1007-30.

6. Structured patient education in Diabetes, Structured Patient Education in Diabetes - Report from the Patient Education Working Group Department of Health; Diabetes UK. June 2005.

7. Patient Education. Adult Diabetes Educartion. Joslin Diabetes Center. Available at http://www.joslin.org/care/patient-education. Accessed 20/09/15.

8. Bartlett EE. Historical glimpses of patient education in the United States. Patient Educ Couns. 1986;8(2):135-49.

9. Mensing $\mathrm{C}$, Boucher J, Cypress $\mathrm{M}$, Weinger $\mathrm{K}$, Mulcahy K, Barta P, et al. National standards for diabetes self-management education. Task Force to Review and Revise the National Standards for Diabetes Self-Management Education Programs. Diabetes Care. 2000;23(5):682-9.

10. National service framework for diabetes: Standards. Department of Health. Dec 2001. Available at www.gov.uk/government/publications/nationalservice-framework-diabetes. Accessed 21/09/15

11. Braun A, Samann A, Kubiak T, Zieschang T, Kloos C, Muller UA, et al. Effects of metabolic control, patient education and initiation of insulin therapy on the quality of life of patients with type 2 diabetes mellitus. Patient Educ Couns. 2008;73(1):50-9.

12. Brown SA. Meta-analysis of diabetes patient education research: variations in intervention effects across studies. Res Nurs Health. 1992;15(6):409-19.

13. Davies MJ, Heller S, Skinner TC, Campbell MJ, Carey ME, Cradock S, et al. Effectiveness of the diabetes education and self management for ongoing and newly diagnosed (DESMOND) programme for people with newly diagnosed type 2 diabetes: cluster randomised controlled trial. Bmj. 2008;336(7642):491-5.

14. Deakin TA, Cade JE, Williams R, Greenwood DC. Structured patient education: the diabetes X-PERT Programme makes a difference. Diabet Med. 2006;23(9):944-54.

15. Jacobs-van der Bruggen MA, van Baal PH, Hoogenveen RT, Feenstra TL, Briggs AH, Lawson $\mathrm{K}$, et al. Cost-effectiveness of lifestyle modification in diabetic patients. Diabetes Care. 2009;32(8):1453-8.

16. Norris SL, Lau J, Smith SJ, Schmid CH, Engelgau MM. Self-Management education for adults with type 2 Diabetes A meta-analysis of the effect on glycemic control. Diabetes Care. 2002;25(7):115971.

17. Sperl-Hillen J, Beaton S, Fernandes O, Von Worley A, Vazquez-Benitez G, Hanson A, et al. Are benefits from diabetes self-management education sustained? Am J Manag Care. 2013;19(2):104-12.

18. Group UPDSU. Effect of intensive blood-glucose control with metformin on complications in overweight patients with type 2 diabetes (UKPDS 34). Lancet. 1998;352:854-65.

19. The effect of intensive treatment of diabetes on the development and progression of long-term complications in insulin-dependent diabetes mellitus. The Diabetes Control and Complications Trial Research Group. N Engl J Med. 1993;329(14):977-86.

20. Third-party reimbursement for diabetes care, selfmanagement education, and supplies. Diabetes Care. 2014;37(1):dc14-S118.

21. Liberati A AD, Tetzlaff J, Mulrow C, Gøtzsche PC, Ioannidis JPA, Clarke M, Devereaux PJ, Kleijnen J, D M. The PRISMA statement for reporting systematic reviews and meta-analyses of studies that evaluate healthcare interventions: explanation and elaboration. Bmj. 2009;339(b2700).

22. Grade Profiler Version 3.6. Available at http://gradeprofiler.software.informer.com/3.6/. Accessed 20/07/2015.

23. Schunemann HJ OA, Vist GE, Higgins JPT, Deeks JJ, Glasziou P, GH. G. Interpreting results and drawing conclusions. In: Higgins JPT, Green S, editors. Cochrane Handbook for Systematic Reviews of Interventions. Chichester (UK): John Wiley \& Sons; 2008. p. 359-87.

24. Higgins JPT AD, Sterne JAC. Assessing risk of bias in included studies. In: Higgins JPT, Green S, editors. Cochrane Handbook for Systematic Reviews of Interventions Version 510 [updated March 2011] available from wwwcochrane-handbookorg. Chichester (UK): John Wiley \& Sons; 2008. p. 187-241. 
25. Scain SF, Friedman R, Gross JL. A structured educational program improves metabolic control in patients with type 2 diabetes: a randomized controlled trial. Diabetes Educ. 2009;35(4):603-11.

26. Cooper H, Booth K, Gill G. A trial of empowerment-based education in type 2 diabetes--global rather than glycaemic benefits. Diabetes Res Clin Pract. 2008;82(2): 165-71.

27. Goudswaard AN, Stolk RP, Zuithoff NP, de Valk HW, Rutten GE. Long-term effects of selfmanagement education for patients with Type 2 diabetes taking maximal oral hypoglycaemic therapy: a randomized trial in primary care. Diabet Med. 2004;21(5):491-6.

28. Lorig K, Ritter PL, Villa FJ, Armas J. Communitybased peer-led diabetes self-management: a randomized trial. Diabetes Educ. 2009;35(4):641-51.

29. Guo XH, Ji LN, Lu JM, Liu J, Lou QQ, Shen L, et al. Efficacy of structured education in patients with type 2 diabetes mellitus receiving insulin treatment. J Diabetes. 2014;6(4):290-7.

30. Kim SI, Kim HS. Effectiveness of mobile and internet intervention in patients with obese type 2 diabetes. Int J Med Inform. 2008;77(6):399-404.

31. Trento M, Gamba S, Gentile L, Grassi G, Miselli V, Morone G, et al. Rethink Organization to iMprove Education and Outcomes (ROMEO): a multicenter randomized trial of lifestyle intervention by group care to manage type 2 diabetes. Diabetes Care. 2010;33(4):745-7.

32. M.M. Funnell RMA, Patient empowerment: a look back, a look ahead, Diab. Educ. 29 (2003) 454-458.

33. Kim MT, Han HR, Song HJ, Lee JE, Kim J, Ryu JP, et al. A community-based, culturally tailored behavioral intervention for Korean Americans with type 2 diabetes. Diabetes Educ. 2009;35(6):986-94.

34. Chao Y-H, Usher K, Buettner PG, Holmes C. Cluster randomised controlled trial: Educational self-care intervention with older Taiwanese patients with Type 2 diabetes mellitus-Impact on blood glucose levels and diabetic complications. Collegian. 2014;21(1):43-51.

35. Prezio EA, Cheng D, Balasubramanian BA, Shuval K, Kendzor DE, Culica D. Community Diabetes Education (CoDE) for uninsured Mexican Americans: a randomized controlled trial of a culturally tailored diabetes education and management program led by a community health worker. Diabetes Res Clin Pract. 2013;100(1):19-28.

36. Welch G, Allen NA, Zagarins SE, Stamp KD, Bursell SE, Kedziora RJ. Comprehensive diabetes management program for poorly controlled Hispanic type 2 patients at a community health center. Diabetes Educ. 2011;37(5):680-8.
37. Mohamed H, Al-Lenjawi B, Amuna P, Zotor F, Elmahdi H. Culturally sensitive patient-centred educational programme for self-management of type 2 diabetes: a randomized controlled trial. Prim Care Diabetes. 2013;7(3):199-206.

38. Aghamolaei T, Eftekhar H, Mohammad K, Nakhjavani $M$, Shojaeizadeh D, Ghofranipour F, et al. Effects of a health education program on behavior, $\mathrm{HbA1c}$ and health-related quality of life in diabetic patients. Acta Medica Iranica. 2005;43(2):89-94.

39. Adachi M, Yamaoka K, Watanabe M, Nishikawa M, Hida E, Kobayashi I, et al. Effects of lifestyle education program for type 2 diabetes patients in clinics: study design of a cluster randomized trial. $B M C$ Public Health. 2010;10(742):1471-2458.

40. Sarkadi A, Rosenqvist U. Experience-based group education in Type 2 diabetes: a randomised controlled trial. Patient Educ Couns. 2004;53(3):291-8.

41. Thom DH, Ghorob A, Hessler D, De Vore D, Chen E, Bodenheimer TA. Impact of peer health coaching on glycemic control in low-income patients with diabetes: a randomized controlled trial. Ann Fam Med. 2013;11(2):137-44.

42. Mollaoglu M, Beyazit E. Influence of diabetic education on patient metabolic control. Appl Nurs Res. 2009;22(3):183-90.

43. Telle-Hjellset V, Raberg Kjollesdal MK, Bjorge B, Holmboe-Ottesen G, Wandel M, Birkeland KI, et al. The InnvaDiab-DE-PLAN study: a randomised controlled trial with a culturally adapted education programme improved the risk profile for type 2 diabetes in Pakistani immigrant women. $B r \quad J$ Nutr. 2013;109(3):529-38.

44. Lujan J, Ostwald SK, Ortiz M. Promotora diabetes intervention for Mexican Americans. Diabetes Educ. 2007;33(4):660-70.

45. Fokkens AS, Wiegersma PA, Beltman FW, Reijneveld SA. Structured primary care for type 2 diabetes has positive effects on clinical outcomes. $J$ Eval Clin Pract. 2011;17(6):1083-8.

46. Davis RM, Hitch AD, Salaam MM, Herman WH, Zimmer-Galler IE, Mayer-Davis EJ. TeleHealth improves diabetes self-management in an underserved community: diabetes TeleCare. Diabetes Care. 2010;33(8):1712-7.

47. Trouilloud D, Regnier J. Therapeutic education among adults with type 2 diabetes: effects of a threeday intervention on perceived competence, selfmanagement behaviours and glycaemic control. Glob Health Promot. 2013;20(2 Suppl):94-8.

48. Carter EL, Nunlee-Bland G, Callender C. A patientcentric, provider-assisted diabetes telehealth selfmanagement intervention for urban minorities. Perspect Health Inf Manag. 2011;1(8). 
49. Deakin T, McShane CE, Cade JE, Williams RD. Group based training for self-management strategies in people with type 2 diabetes mellitus. Cochrane Database Syst Rev. 2005;18(2).

50. Graziano JA, Gross CR. A randomized controlled trial of an automated telephone intervention to improve glycemic control in type 2 diabetes. $A N S A d v$ Nurs Sci. 2009;32(3).

51. Aubert RE, Herman WH, Waters J, Moore W, Sutton D, Peterson BL, et al. Nurse case management to improve glycemic control in diabetic patients in a health maintenance organization. A randomized, controlled trial. Ann Intern Med. 1998;129(8):60512.

52. Glasgow RE, Anderson RM. In diabetes care, moving from compliance to adherence is not enough. Something entirely different is needed: Diabetes Care. 1999 Dec;22(12):2090-2.

53. Jarvis J, Skinner TC, Carey ME, Davies MJ. How can structured self-management patient education improve outcomes in people with type 2 diabetes? Diabetes Obes Metab. 2010;12(1):12-9.

54. Debussche X, Balcou-Debussche M, Besançon S, Traore S. Challenges to diabetes self-management in developing countries. Diabetes Voice. 2009;54:12-4.

55. Healthcare Commission. Managing Diabetes: Improving Services for People with Diabetes. Healthcare commission, London, 2007. Available at www.yearofcare.co.uk/sites/default/files/pdfs/Mana ging_diabetes.pdf. Accessed 19/08/15

56. Samuel-Hodge CD, Keyserling TC, Park S, Johnston LF, Gizlice Z, Bangdiwala SI. A randomized trial of a church-based diabetes self-management program for African Americans with type 2 diabetes. Diabetes Educ. 2009;35(3):439-54.

57. Norris SL, Engelgau MM, Narayan KM. Effectiveness of self-management training in type 2 diabetes: a systematic review of randomized controlled trials. Diabetes Care. 2001;24(3):561-87.

58. Norris SL, Lau J, Smith SJ, Schmid CH, Engelgau MM. Self-management education for adults with type 2 diabetes: a meta-analysis of the effect on glycemic control. Diabetes Care. 2002;25(7):1159-71.

59. Nathan DM, Buse JB, Davidson MB, Ferrannini E, Holman RR, Sherwin R, et al. Management of hyperglycemia in type 2 diabetes: a consensus algorithm for the initiation and adjustment of therapy: update regarding thiazolidinediones: a consensus statement from the American Diabetes Association and the European Association for the Study of Diabetes. Diabetes Care. 2008;31(1):173-5.

60. Sperl-Hillen J, Beaton S, Fernandes O, Von Worley A, Vazquez-Benitez G, Parker E, et al. Comparative effectiveness of patient education methods for type 2 diabetes: a randomized controlled trial. Arch Intern Med. 2011;171(22):2001-10.

61. Ahren B. Avoiding hypoglycemia: a key to success for glucose-lowering therapy in type 2 diabetes. Vasc Health Risk Manag. 2013;9:155-63.

62. Moher D, Pham B, Klassen TP, Schulz KF, Berlin JA, Jadad AR, et al. What contributions do languages other than English make on the results of meta-analyses? J Clin Epidemiol. 2000;53(9):96472.

63. Mash R, Rhode H, Zwarenstein M, Rollnick S, Lombard C, Steyn K, et al. Research: Educational and Psychological Issues Effectiveness of a group diabetes education programme in under-served communities in South Africa: a pragmatic cluster randomized controlled trial. Diabetic Medicine. 2014;31(8):987.

64. Mons U, Raum E, Kramer HU, Ruter G, Rothenbacher D, Rosemann T, et al. Effectiveness of a supportive telephone counseling intervention in type 2 diabetes patients: randomized controlled study. PLoS One. 2013;8(10).

65. Ko GT, Li JK, Kan EC, Lo MK. Effects of a structured health education programme by a diabetic education nurse on cardiovascular risk factors in Chinese Type 2 diabetic patients: a 1-year prospective randomized study. Diabet Med. 2004;21(12):1274-9.

66. Moriyama M, Nakano M, Kuroe Y, Nin K, Niitani M, Nakaya T. Efficacy of a self-management education program for people with type 2 diabetes: results of a 12 month trial. Jpn J Nurs Sci. 2009;6(1):51-63.

67. Rygg LO, Rise MB, Gronning K, Steinsbekk A. Efficacy of ongoing group based diabetes selfmanagement education for patients with type 2 diabetes mellitus. A randomised controlled trial. Patient Educ Couns. 2012;86(1):98-105.

68. Steed L, Lankester J, Barnard M, Earle K, Hurel S, Newman S. Evaluation of the UCL diabetes selfmanagement programme (UCL-DSMP): a randomized controlled trial. $J$ Health Psychol. 2005;10(2):261-76.

69. Adolfsson ET, Walker-Engstrom ML, Smide B, Wikblad K. Patient education in type 2 diabetes: a randomized controlled 1-year follow-up study. Diabetes Res Clin Pract. 2007;76(3):341-50.

70. Sturt JA, Whitlock S, Fox C, Hearnshaw H, Farmer AJ, Wakelin M, et al. Effects of the Diabetes Manual 1:1 structured education in primary care. Diabet Med. 2008;25(6):722-31.

71. Sonnichsen AC, Winkler H, Flamm M, Panisch S, Kowatsch P, Klima G, et al. The effectiveness of the Austrian disease management programme for type 2 diabetes: a cluster-randomised controlled trial. $B M C$ Fam Pract. 2010;11(86):1471-229 


\begin{tabular}{|c|c|c|c|c|c|}
\hline $\begin{array}{l}\text { Study } \\
\text { No } \\
\text { (Ref) }\end{array}$ & $\begin{array}{l}\text { First Author, } \\
\text { Country, } \\
\text { Year of publication }\end{array}$ & $\begin{array}{l}\text { Participants } \\
\text { characteristics, } \\
\text { Sample size (N), } \\
\text { Mean Age } \\
\end{array}$ & $\begin{array}{l}\text { Intervention (I) /Control (C) } \\
\text { methods, } \\
\text { Follow up and Duration of study }\end{array}$ & Outcome measure & Outcomes/Conclusions \\
\hline $1^{33}$ & $\begin{array}{l}\text { Kim MT } \\
\text { USA } \\
2009\end{array}$ & $\begin{array}{l}\text { Korean Immigrants with } \\
\text { poor glucose control, Alc } \\
\geq 7.5 \% \\
\mathrm{~N}=79(\mathrm{I}=40 ; \mathrm{C}=39) \\
\text { Mean age }=56.4 \text { years }\end{array}$ & $\begin{array}{l}\text { I: Structured 6-week education (2- } \\
\text { hour weekly), and then home } \\
\text { glucose monitoring with tele- } \\
\text { transmission, and bilingual Nurse } \\
\text { telephone counselling for } 24 \text { weeks. } \\
\text { C: Delayed intervention }\end{array}$ & $\begin{array}{l}\text { Primary outcome was } \\
\text { decrease in A1C level at } \\
18 \text { and } 30 \text { weeks; } \\
\text { Goal: A1c }<7 \%\end{array}$ & $\begin{array}{l}\text { Significant reduction in } \mathrm{A} 1 \mathrm{C} \text { among intervention group compared to controls, } \\
\mathrm{p}=0.0018 \text { weeks and } \mathrm{p}=0.01 \text { at } 30 \text { weeks. } \\
\text { Conclusion: } \\
\text { Culturally tailored comprehensive type } 2 \text { diabetes management intervention for } \\
\text { Korean American immigrants (KAIs) is effective in significantly reduces A1c } \\
\text { levels at } 18 \text { weeks and sustained at } 30 \text { weeks }\end{array}$ \\
\hline $2^{56}$ & $\begin{array}{l}\text { Samuel-Hodge CD } \\
\text { USA } \\
2009\end{array}$ & $\begin{array}{l}\text { African Americans in } 24 \\
\text { African American churches } \\
\text { in central North Carolina. } \\
\mathrm{N}=201(\mathrm{I}=117 ; \mathrm{C}=84) \\
\text { Mean age }=59 \text { years }\end{array}$ & $\begin{array}{l}\text { I: } 8 \text {-month intensive phase: } \\
\text { individual counselling visit, group } \\
\text { sessions, monthly phone contacts, } \\
\text { encouragement postcards; followed } \\
\text { by a 4-month reinforcement phase: } \\
\text { monthly phone contacts. } \\
\text { C: Standard educational } \\
\text { pamphlets by mail. }\end{array}$ & $\begin{array}{l}\text { Primary outcome was } \\
\text { comparison of } \\
\text { 8-month A1C levels }\end{array}$ & $\begin{array}{l}\text { 8-month measures: } 174(87 \%) \text {, mean } \mathrm{A} 1 \mathrm{C} \text { (adjusted for baseline and group } \\
\text { randomization) was } 7.4 \% \text { for I and } 7.8 \% \text { for } \mathrm{C} \text {, } \\
\text { ( } 95 \% \text { confidence interval [CI] } 0.1-0.6, P=.009) \text {. } \\
12 \text { months measures: difference between groups not significant } \\
\text { Conclusion: } \\
\text { Church-based structured diabetes intervention was well received by participants } \\
\text { and improved short-term metabolic control. }\end{array}$ \\
\hline $3^{25}$ & $\begin{array}{l}\text { Scain S F } \\
\text { Brazil } \\
2009\end{array}$ & $\begin{array}{l}\text { Type } 2 \text { patients from } \\
\text { public Teaching hospital } \\
\text { and tertiary care centre } \\
\text { with average diabetes } \\
\text { duration of } 10.5 \text { years } \\
\mathrm{N}=104(\mathrm{I}=52 ; \mathrm{C}=52) \\
\text { Mean age }=59 \text { years }\end{array}$ & $\begin{array}{l}\text { I: 8-hour structured group education } \\
\text { program structured based on the } \\
\text { Latin American Diabetes } \\
\text { Association programme for health } \\
\text { care providers } \\
\text { C: Usual care; control group had } 3 \\
\text { hospital visits in a year like the } \\
\text { intervention group. }\end{array}$ & $\begin{array}{l}\text { Main outcome } \\
\text { measures were A1C, } \\
\text { weight, blood pressure, } \\
\text { and lipids at } 4 \text {-month } \\
\text { intervals, up to } 12 \\
\text { months. }\end{array}$ & $\begin{array}{l}\text { HbA1c was statistically different between the } 2 \text { groups at } 4(P=.007), 8(P= \\
.009) \text {, and } 12 \text { months }(P=.04) \text {. } \\
\text { Conclusion: } \\
\text { A structured group educational programme centred on self-management } \\
\text { improves glycaemic control in patients with type } 2 \text { diabetes attending a tertiary } \\
\text { health Care facility (even if basal A1C levels are already }<7 \% \text {. Though there } \\
\text { was loss of momentum at after } 4 \text { months, improvement lasts for up to } 12 \\
\text { months. }\end{array}$ \\
\hline $4^{26}$ & $\begin{array}{l}\text { Cooper H. } \\
\text { UK } \\
2008\end{array}$ & $\begin{array}{l}\text { Patients with } T 2 D \text { for } \\
\text { averagely } 6 \text { years who } \\
\text { attends at least once yearly } \\
\text { annual review } \\
\mathrm{N}=89(\mathrm{I}=53 ; \mathrm{C}=59) \\
\text { Mean age }=59 \text { years }\end{array}$ & $\begin{array}{l}\text { I: } 3 \text { outpatient centres involved: } \\
\text { Empowerment-based educational } \\
\text { system was the intervention } \\
\text { method. } \\
\text { C: Standard support. All patients } \\
\text { eventually had the empowerment } \\
\text { education. }\end{array}$ & $\begin{array}{l}\text { Outcome measures: } \\
\text { HbA1c, and a variety of } \\
\text { quantitative, } \\
\text { psychological and } \\
\text { educational measures } \\
\text { assessed at } 6 \text { months } \\
\text { ('short-term') and } 12 \\
\text { months ('long-term') } \\
\text { post-intervention. }\end{array}$ & $\begin{array}{l}\text { Benefits in HbAlc levels at } 6 \text { months follow-up among the intervention group } \\
\text { compared to controls }(p=0.005) \text {, illness attitudes }(p=0.04) \text {, and perceived } \\
\text { treatment effectiveness }(p=0.03) \text {. } \\
\text { At } 12 \text { months however, only illness attitudes }(p=0.01) \text {, and self-monitoring (p } \\
=0.002) \text { showed benefit. } \\
\text { Conclusion: } \\
\text { Benefits in glycaemic control in the short but not long term. }\end{array}$ \\
\hline
\end{tabular}




\begin{tabular}{|c|c|c|c|c|c|}
\hline $\begin{array}{l}\text { Study } \\
\text { No } \\
\text { (Ref) }\end{array}$ & $\begin{array}{l}\text { First Author, } \\
\text { Country, } \\
\text { Year of } \\
\text { publication }\end{array}$ & $\begin{array}{l}\text { Participants characteristics, } \\
\text { Sample size (N), } \\
\text { Mean Age }\end{array}$ & $\begin{array}{l}\text { Intervention (I) /Control (C) methods, } \\
\text { Follow up and Duration of study }\end{array}$ & Outcome measure & Outcomes/Conclusions \\
\hline $5^{34}$ & $\begin{array}{l}\text { Chao YH } \\
\text { TAIWAN } \\
2012\end{array}$ & $\begin{array}{l}\text { Elderly Taiwanese with Type } \\
2 \text { DM } \\
\mathrm{N}=500(\mathrm{I}=241, \mathrm{C}=259) \\
\text { ? Mean age ( } 50-80 \text { years })\end{array}$ & $\begin{array}{l}12 \text { clinics involved; } 6 \text { each arm } \\
\text { I: specially designed information } \\
\text { booklet on diabetes plus additional } 1 \mathrm{~h} \\
\text { diabetes education session delivered in } \\
\text { groups every week for three weeks. } \\
\text { C: Only specially designed information } \\
\text { booklet on diabetes }\end{array}$ & $\begin{array}{l}\text { Clinical outcome measures } \\
\text { included glycosylated } \\
\text { haemoglobin, urine protein, } \\
\text { lipids, diabetes related } \\
\text { complications etc. } \\
\text { Assessment done at } 3 \text { and } 6 \\
\text { months. }\end{array}$ & $\begin{array}{l}\text { At } 6 \text { months, } 92.4 \% \text { for the control group had above normal blood } \\
\text { glucose levels and } 60.4 \% \text { for the experimental group }(p<0.001) \\
\text { Multivariate adjusted result showed that the intervention group was } 11.1 \\
\text { times less likely to have blood glucose levels above normal }(p=0.002) \text { at } \\
6 \text { months follow-up compared to the control group }\end{array}$ \\
\hline $6^{35}$ & $\begin{array}{l}\text { Prezio EA. } \\
\text { USA } \\
2013\end{array}$ & $\begin{array}{l}\text { Uninsured Mexican } \\
\text { Americans with type } 2 \\
\text { diabetes attending a urban } \\
\text { faith-based community health } \\
\text { services clinic in Dallas } \\
\mathrm{N}=180 \text { (I=90,C=90) } \\
\text { Mean age }=49.7 \text { (18-75 years) }\end{array}$ & $\begin{array}{l}\text { I: Usual care plus Community Diabetes } \\
\text { Education (CoDE) program over } 12 \\
\text { months impact using a culturally } \\
\text { tailored diabetes education program led } \\
\text { by a community health worker (CHW). } \\
\text { Follow up for } 12 \text { months } \\
\text { C: Usual care; plus glucometers and } \\
\text { strips }\end{array}$ & $\begin{array}{l}\text { The primary outcome of interest } \\
\text { was HbA1c. } \\
\text { Secondary outcomes included } \\
\text { blood pressure, BMI and lipid } \\
\text { status }\end{array}$ & $\begin{array}{l}\text { Mean changes of HbAlc over } 12 \text { months showed a significant } \\
\text { intervention effect }(-0.7 \%, \mathrm{p}=0.02) \text { in the CoDE group compared with } \\
\text { controls. HbAlc decreased significantly from baseline to } 12 \text { months } \\
\text { within the intervention }(-1.6 \%, \mathrm{p}<.001) \text { and control } \\
(=.9 \%, \mathrm{p}<.001) \text { groups. No differences between groups for secondary } \\
\text { outcomes were found. } \\
\text { Conclusions: This study supports the effectiveness of CHWs as diabetes } \\
\text { educators/case managers }\end{array}$ \\
\hline $7^{28}$ & $\begin{array}{l}\text { Lorig K. } \\
\text { USA } \\
2009\end{array}$ & $\begin{array}{l}\text { Type } 2 \text { diabetes patients from } \\
\text { churches and senior centres } \\
\mathrm{N}=345 \text { (I=186, C: } 159) \\
\text { Mean age }=66.7(24-93 \\
\text { years) }\end{array}$ & $\begin{array}{l}\text { I: } 6 \text {-week community-based, peer-led } \\
\text { diabetes self-management program } \\
\text { (DSMP) consisting of } 2 \frac{1}{2} \text { hours weekly } \\
\text { by } 2 \text { peer leaders. Class sizes ranged } \\
\text { from } 10 \text { to } 15 \text {. } \\
\text { After } 6 \text { months Intervention group had } \\
\text { additional } 6 \text { months of longitudinal } \\
\text { follow up. } \\
\text { C: Usual care, but offered DSMP after } 6 \\
\text { months }\end{array}$ & $\begin{array}{l}\text { A1C and body mass index were } \\
\text { measured at baseline, } 6 \text { months, } \\
\text { and } 12 \text { months. All other data } \\
\text { were collected by self- } \\
\text { administered questionnaires. }\end{array}$ & $\begin{array}{l}\text { At } 6 \text { months, DSMP participants did not demonstrate significant } \\
\text { improvements in A1C as compared with controls }(\mathrm{p}>0.05) \\
\text { At } 12 \text { months, DSMP intervention participants continued to demonstrate } \\
\text { improvements in depression, communication with physicians, healthy } \\
\text { eating, patient activation, and self-efficacy }(P<.01) \text {. } \\
\text { Conclusions: } \\
\text { A community-based, peer led diabetes programme for people with } \\
\text { diabetes without elevated A1C resulted in significant benefits but not in } \\
\text { glycaemic control. }\end{array}$ \\
\hline $8^{36}$ & $\begin{array}{l}\text { Welch G. } \\
\text { USA }\end{array}$ & $\begin{array}{l}\text { Adults Hispanics controlled } \\
\text { Hispanic type } 2 \text { diabetes } \\
\text { (T2DM) patients in an } \\
\text { Urban community health } \\
\text { centre setting } \\
\mathrm{N}=39 \text { (I=21,C=18) } \\
\text { Mean age 55. } 8 \text { (30-85 years) }\end{array}$ & $\begin{array}{l}\text { Nurse-led diabetes care program } \\
\text { (Comprehensive Diabetes Management } \\
\text { Program, CDMP), is an interactive, } \\
\text { Web-based, diabetes management tool } \\
\text { based PLUS seven 1-hour diabetes care } \\
\text { visits over a 12-month period. } \\
\text { C: attention control condition- } \\
\text { consisting of seven 1-hour visits over a } \\
\text { 12-month period. }\end{array}$ & $\begin{array}{l}\text { Comparison were made between } \\
\text { the two arms in terms of blood } \\
\text { glucose, blood pressure, foot } \\
\text { exam, eye exam, and levels of } \\
\text { diabetes distress, depression, and } \\
\text { treatment satisfaction at baseline } \\
\text { and at } 12 \text { months. }\end{array}$ & $\begin{array}{l}\text { I } \\
\text { Intervention patients had a significant improvement in } \mathrm{A} 1 \mathrm{C} \text { from baseline } \\
\text { to } 12 \text {-month follow-up compared with control group }(-1.6 \% \pm 1.4 \% \\
\text { versus }-0.6 \% \pm 1.1 \% ; P=.01) \text {. } \\
\text { Conclusion } \\
\text { The CDMP intervention was more effective than an attention control } \\
\text { condition in helping patients meet evidence-based guidelines for diabetes } \\
\text { care }\end{array}$ \\
\hline
\end{tabular}




\begin{tabular}{|c|c|c|c|c|c|}
\hline $\begin{array}{l}\text { Study } \\
\text { No } \\
\text { (Ref) }\end{array}$ & $\begin{array}{l}\text { First Author, } \\
\text { Country, } \\
\text { Year of } \\
\text { publication }\end{array}$ & $\begin{array}{l}\text { Participants characteristics, } \\
\text { Sample size (N), } \\
\text { Mean Age }\end{array}$ & $\begin{array}{l}\text { Intervention (I) /Control (C) methods, } \\
\text { Follow up and Duration of study }\end{array}$ & Outcome measure & Outcomes/Conclusions \\
\hline $9^{37}$ & $\begin{array}{l}\text { Mohammed } \\
\text { QATAR } \\
2013\end{array}$ & $\begin{array}{l}\text { Adult Type } 2 \text { Arabs living in } \\
\text { Qatar and registered with } \\
\text { primary health care }(\mathrm{PHC}) \\
\text { centres and the Main General } \\
\text { Hospital (HGH). } \\
\mathrm{N}=430 \text { (I=215, C=215) } \\
\text { Mean Age } 53.5 \text { years }\end{array}$ & $\begin{array}{l}\text { I: It consisted of four structured group } \\
\text { based educational sessions for each } \\
\text { group of patients ( } 10-20 \text { patients per } \\
\text { session), lasting for } 3-4 \mathrm{~h} \text {; PLUS } \\
\text { diabetes educational toolkit. } \\
\text { Follow up was } 12 \text { months } \\
\begin{array}{l}\text { C: Routine care plus Diabetes } \\
\text { educational toolkit only }\end{array}\end{array}$ & $\begin{array}{l}\text { Primary outcomes included } \\
\text { reduction in HbA1c, F.P.G, lipid } \\
\text { profile, albumin/creatinine ratio, } \\
\text { BMI and blood pressure. } \\
\text { Outcomes were assessed at base } \\
\text { line and } 12 \text { months after } \\
\text { intervention. }\end{array}$ & $\begin{array}{l}\text { The intervention led to a statistically significant reduction in } \mathrm{HbA1C} \text { in } \\
\text { the (CSSEP) group }(-0.55 \mathrm{mmol} / \mathrm{L}, P=0.012) \text {, fasting blood sugar } \\
(-0.92 \mathrm{mmol} / \mathrm{L}, P=0.022), \text { body mass index }(1.70, P=0.001) \text { and } \\
\text { albumin/creatinine ratio }(-3.09, P<0.0001) \text { but not in the control group. } \\
\text { Conclusion: } \\
\text { Culturally sensitive patient-centred educational programme for self- } \\
\text { management of type } 2 \text { diabetes improves glycaemic control and other } \\
\text { parameters }\end{array}$ \\
\hline $10^{13}$ & $\begin{array}{l}\text { Davies MJ } \\
\text { UK } \\
2008\end{array}$ & $\begin{array}{l}\text { Newly diagnosed } \\
\text { type } 2 \text { diabetes mellitus from } \\
207 \text { general practices across } \\
\text { UK; cluster randomised with } \\
\text { trial randomisation at } \\
\text { practice level } \\
\mathrm{N}:=824(\mathrm{I}=437, \mathrm{C}=387) \\
\text { Mean Age }=59.5\end{array}$ & $\begin{array}{l}\text { I: A structured group education } \\
\text { programme (DESMOND) for six hours } \\
\text { delivered (within } 6 \text { weeks of diagnosis) } \\
\text { in the community by two trained } \\
\text { healthcare professional educators, } \\
\text { follow up were four, eight, and } 12 \\
\text { months. } \\
\text { C: Usual care. }\end{array}$ & $\begin{array}{l}\text { Impact of DESMOND on HBA1c } \\
\text { levels, blood pressure, weight, } \\
\text { blood lipid levels, smoking status, } \\
\text { physical activity, quality of life, } \\
\text { beliefs about illness, depression, } \\
\text { and emotional impact of diabetes } \\
\text { at baseline and up to } 12 \text { months. }\end{array}$ & $\begin{array}{l}\text { HbAlc levels at } 12 \text { months had decreased by } 1.49 \% \text { in the intervention } \\
\text { group compared with } 1.21 \% \text { in the control group. After adjusting for } \\
\text { baseline and cluster, the difference was not significant: } 0.05 \%(95 \% \\
\text { confidence interval-0.10\% to } 0.20 \%) \text {. } \\
\text { Conclusion: } \\
\text { DESMOND resulted in greater improvements in weight loss and smoking } \\
\text { cessation and positive improvements in beliefs about illness but no } \\
\text { difference in Alc levels up to } 12 \text { months after diagnosis }\end{array}$ \\
\hline $11^{63}$ & $\begin{array}{l}\text { Mash RJ } \\
\text { South Africa }\end{array}$ & $\begin{array}{l}\text { Working class Type } 2 \\
\text { diabetes in public sector } \\
\text { community health centres in } \\
\text { Cape Town. } \\
\mathrm{N}=1570(\mathrm{I}=860, \mathrm{C}=710) \\
\text { Mean Age }=56.1 \text { years }\end{array}$ & $\begin{array}{l}\text { I: A total of four monthly sessions ( } 60 \\
\text { mins each) of group diabetes education } \\
\text { led by a health promoter. Participants } \\
\text { were assessed at baseline and } 12 \text { months } \\
\text { later. } \\
\text { C: Usual care }\end{array}$ & $\begin{array}{l}\text { Primary outcomes were diabetes } \\
\text { self-care activities, } 5 \% \text { weight } \\
\text { loss reduction in } \mathrm{HbAlc} \text { levels }\end{array}$ & $\begin{array}{l}\text { No significant improvement was found in any of the primary or } \\
\text { secondary outcomes, apart from a significant reduction in } \\
\text { mean systolic }(-4.65 \mathrm{mmHg}, 95 \% \mathrm{CI} 9.18 \text { to }-0.12 ; \mathrm{P}=0.04) \text { and } \\
\text { diastolic blood pressure }(-3.30 \mathrm{mmHg}, 95 \% \mathrm{CI}-5.35 \\
\text { to }-1.26 ; \mathrm{P}=0.002) \text {. } \\
\text { Conclusion: } \\
\text { The reported effectiveness of group diabetes education offered by more } \\
\text { highly trained professionals, in well-resourced settings, was not replicated } \\
\text { in the present study }\end{array}$ \\
\hline $12^{64}$ & $\begin{array}{l}\text { Mons U } \\
\text { Germany } \\
2013\end{array}$ & $\begin{array}{l}\text { Adult type } 2 \text { patients from } 38 \\
\text { general practices in Germany } \\
\mathrm{N}=204(\mathrm{I}=103, \mathrm{C}=101) \\
\text { Mean Age } 67.5 \text { years }\end{array}$ & $\begin{array}{l}\text { I: Patient-centred supportive counselling } \\
\text { intervention comprising monthly } \\
\text { telephone-based counselling sessions by } \\
\text { practice nurses over } 12 \text { months; sessions } \\
\text { were conducted according to a written } \\
\text { manual and were based on a } \\
\text { standardized questionnaire. } \\
\text { Follow-up-measurements were carried } \\
\text { out after } 6,12 \text { and } 18 \text { months } \\
\text { C: Usual care }\end{array}$ & $\begin{array}{l}\text { The primary outcome was change } \\
\text { in HbA1c-concentration after } 12 \\
\text { (end-of-intervention) and } 18 \\
\text { months ( } 6 \text { months post- } \\
\text { intervention). }\end{array}$ & $\begin{array}{l}\text { HbAlc (in \%) decreased significantly from baseline to } 12 \text {-month follow- } \\
\text { up measurement both in the intervention ( }-0.44, \mathrm{p}<0.001) \text { and the usual } \\
\text { care group }(-0.51, \mathrm{p}<0.001) \text {, but there was no significant between-group } \\
\text { intervention effect. } \\
\text { Conclusions: Although we found no beneficial effect of the supportive } \\
\text { telephone counselling in terms of a reduction of } \\
\text { HbA1c above usual care, though other benefits accrued. }\end{array}$ \\
\hline
\end{tabular}




\begin{tabular}{|c|c|c|c|c|c|}
\hline $\begin{array}{l}\text { Study } \\
\text { No } \\
\text { (Ref) }\end{array}$ & $\begin{array}{l}\text { First Author, } \\
\text { Country, } \\
\text { Year of } \\
\text { publication } \\
\end{array}$ & $\begin{array}{l}\text { Participants characteristics, } \\
\text { Sample size (N), } \\
\text { Mean Age }\end{array}$ & $\begin{array}{l}\text { Intervention (I) /Control (C) methods, } \\
\text { Follow up and Duration of study }\end{array}$ & Outcome measure & Outcomes/Conclusions \\
\hline $13^{38}$ & $\begin{array}{l}\text { Aghamolaei } \\
\text { T. } \\
\text { Iran } \\
2005\end{array}$ & $\begin{array}{l}\text { T2D patients attending at } \\
\text { Bandar Abbas diabetic clinic } \\
\text { Shahid Mohammadi } \\
\text { Hospital in south of Iran. and } \\
\text { had not attended a formal } \\
\text { diabetes education } \\
\mathrm{N}=80(\mathrm{I}=40, \mathrm{C}=40) \\
\text { Mean } \mathrm{Age}=51.2 \text { years }\end{array}$ & $\begin{array}{l}\text { Group (of } 10 \text { ) interactive } 2 \text { hours } \\
\text { weekly (for } 4 \text { weeks) health education } \\
\text { program on knowledge, behaviour, } \\
\text { HbA1c and health-related quality of life } \\
\text { (HRQOL) of diabetic patients PLUS } \\
\text { printed copies of in country diabetes } \\
\text { guidelines. Follow up was } 4 \text { months. } \\
\text { C: Usual care }\end{array}$ & $\begin{array}{l}\text { To assess knowledge, behaviour } \\
\text { change, } \\
\text { Improvement in HbAlc and } \\
\text { health related quality of life } \\
\text { (HRQOL) at baseline and at } 4 \\
\text { months. }\end{array}$ & $\begin{array}{l}\text { The intervention group showed statistically significant increase in mean } \\
\text { of knowledge, behaviour, physical and psychological health and also had } \\
\text { a statistically significant reduction in mean of HbAlc. } \\
\text { Conclusion: } \\
\text { This interactive approach is useful and worthwhile behaviour } \\
\text { modification and improvement in HbAlc and health-related quality of } \\
\text { life of diabetic patients. }\end{array}$ \\
\hline $14^{65}$ & $\begin{array}{l}\text { Ko GTC } \\
\text { China } \\
2005\end{array}$ & $\begin{array}{l}\text { T2D with poor glycaemic } \\
\text { control were recruited from } \\
\text { three regional diabetic } \\
\text { centres in Hong Kong. } \\
\mathrm{N}=180 \text { (I=90,C=90) } \\
\text { Mean Age } 55.0 \text { ( } 35-70 \text { years) }\end{array}$ & $\begin{array}{l}\text { I: Additional structured } 30 \text { minutes } \\
\text { reinforcement of diabetic health } \\
\text { education by a trained nurse after the } \\
\text { doctors' consultations every } 3 \text { months } \\
\text { for } 12 \text { months. } \\
\text { C: Same medical care except no nursing } \\
\text { reinforcement. }\end{array}$ & $\begin{array}{l}\text { Outcome measures included } \\
\text { fasting plasma glucose, HbA1c, } \\
\text { body mass index, waist } \\
\text { circumference, blood pressure } \\
\text { and lipid profiles assessed at } \\
\text { baseline and after } 1 \text { year. }\end{array}$ & $\begin{array}{l}\text { There was a greater drop in } \mathrm{HbAlc} \text { in the intervention group }(6.0 \%) \\
\text { compared with control }(2.1 \%) \text { but when adjusted for age and gender there } \\
\text { was no significant difference ( } \mathrm{p}=0.171) \text {. } \\
\text { Conclusions: } \\
\text { Regular structured reinforcement with diabetic health education useful } \\
\text { helps to control more successfully some of the cardiovascular risk factors } \\
\text { in Chinese Type } 2 \text { diabetic patients. }\end{array}$ \\
\hline $15^{39}$ & $\begin{array}{l}\text { Adachi M. } \\
\text { Japan } \\
2013\end{array}$ & $\begin{array}{l}\text { T2D patients from } 20 \\
\text { primary car e settings in } \\
\text { Japan with } \mathrm{HbAlc} \geq 6.5 \% \\
\mathrm{~N}=193(\mathrm{I}=100, \mathrm{C}=93) \\
\begin{array}{l}\text { Mean } \mathrm{Age}=61.3(20-79 \\
\text { years })\end{array}\end{array}$ & $\begin{array}{l}\text { Structured individual-based lifestyle } \\
\text { education (SILE) program delivered by } \\
\text { registered dieticians in } 4 \text { sessions at } \\
\text { primary care clinical settings with } \\
\text { randomization at the practice level with } \\
\text { six month follow up. } \\
\text { C: Usual care. }\end{array}$ & $\begin{array}{l}\text { The primary endpoint was the } \\
\text { change in HbAlc levels at } 6 \\
\text { months from baseline. }\end{array}$ & $\begin{array}{l}\text { The mean change at } 6 \text { months from baseline in HbA1c was a } 0.7 \% \\
\text { decrease in the intervention group ( } \mathrm{n}=100) \text { and a } 0.2 \% \text { decrease in the } \\
\text { control group ( } \mathrm{n}=93 \text { ) (difference }-0.5 \%, 95 \% \mathrm{CI}:-0.2 \% \text { to }-0.8 \%, \mathrm{p}= \\
0.004 \text { ). After adjusting for baseline values and other factors, the } \\
\text { difference was still significant ( } \mathrm{p}=0.003 \sim 0.011 \text { ). } \\
\text { Conclusions: The SILE program that was provided in primary care } \\
\text { settings for patients with type } 2 \text { diabetes resulted in greater improvement } \\
\text { in HbA1c levels than usual diabetes care and education. }\end{array}$ \\
\hline $16^{66}$ & $\begin{array}{l}\text { Moriyama M. } \\
\text { Japan } \\
2009\end{array}$ & $\begin{array}{l}\text { Type } 2 \text { diabetes from two } \\
\text { hospitals in Japan } \\
\mathrm{N}=75(\mathrm{I}=50, \mathrm{C}=25) \\
\text { Mean Age }=65.8 \text { years }\end{array}$ & $\begin{array}{l}\text { I: } 12 \text { month self-management education- } \\
<30 \text { min of monthly motivational } \\
\text { interviews based on the program's } \\
\text { textbook and biweekly telephone calls } \\
\text { from a nurse educator throughout the } 12 \\
\text { months. } \\
\text { C: Usual care PLUS a commercial } \\
\text { textbook on diabetes. }\end{array}$ & $\begin{array}{l}\text { Final outcomes were the } \\
\text { improvement of the physiological } \\
\text { data including HbAlc related to } \\
\text { the prevention of complications } \\
\text { and an improvement in the QOL. }\end{array}$ & $\begin{array}{l}\text { Within groups, there was significant change in HBA1c values ( } \mathrm{p}=0.00 \mathrm{O}) \\
\text { over the follow up period compared with controls, which did not show } \\
\text { such as change ( } \mathrm{p}=0.448 \text { ). However, over all, there was not statistical } \\
\text { difference between the two groups ( } \mathrm{p}=0.705 \text { ) } \\
\text { Conclusion: } \\
\text { Self-management education works successfully in relation to patients' } \\
\text { behaviour modification skills, degree of goal attainment, and self- } \\
\text { efficacy, consequently improving their health outcomes. }\end{array}$ \\
\hline
\end{tabular}




\begin{tabular}{|c|c|c|c|c|c|}
\hline $\begin{array}{l}\text { Study } \\
\text { No } \\
\text { (Ref) }\end{array}$ & $\begin{array}{l}\text { First Author, } \\
\text { Country, } \\
\text { Year of } \\
\text { publication }\end{array}$ & $\begin{array}{l}\text { Participants characteristics, } \\
\text { Sample size (N), } \\
\text { Mean Age }\end{array}$ & $\begin{array}{l}\text { Intervention (I) /Control (C) methods, } \\
\text { Follow up and Duration of study }\end{array}$ & Outcome measure & Outcomes/Conclusions \\
\hline $17^{67}$ & $\begin{array}{l}\text { Rygg LO. } \\
\text { Norway } \\
2009\end{array}$ & $\begin{array}{l}\text { T2D patients who } \\
>18 \text { years old and who had } \\
\text { been to a GP consultation in } \\
\text { the previous } 3 \text { years with no } \\
\text { preset A1C cut-off values } \\
\text { were referred to } 2 \text { hospitals } \\
\mathrm{N}=146(\mathrm{I}=73, \mathrm{C}=73) \\
\text { Mean Age }=66 \text { ( } 40-75 \text { years) }\end{array}$ & $\begin{array}{l}\text { I: Structured Education delivered by } \\
\text { diabetes nurses lasts for } 15 \mathrm{~h} \text { over three } \\
\text { sessions with } 1-2 \text { week between each } \\
\text { session. } \\
\text { C: Waiting list control PLUS usual care. }\end{array}$ & $\begin{array}{l}\text { Primary outcomes were } \mathrm{A} 1 \mathrm{C} \text { and } \\
\text { patient activation measured with } \\
\text { patient activation measure (PAM) } \\
\text { at } 6 \text { and } 12 \text { months. }\end{array}$ & $\begin{array}{l}\text { No differences in the primary outcomes between the groups at } 12 \text { months, } \\
\text { but the control group had an increase in A1C of } 0.3 \% \text { points during } \\
\text { follow-up. } \\
\text { Sub group analysis for the quartile with the highest A1C at baseline } \\
(>7.7, \mathrm{n}=18 \text { in both groups) revealed significant improvements within } \\
\text { the intervention group at } 12 \text { month follow-up for both A1C and PAM and } \\
\text { a trend for better outcome in the intervention group compared to the } \\
\text { control } \\
\text { Conclusions: The locally developed ongoing diabetes self-management } \\
\text { education programs prevented an increase in A1C }\end{array}$ \\
\hline $18^{68}$ & $\begin{array}{l}\text { Steed L. } \\
\text { UK }\end{array}$ & $\begin{array}{l}\text { T2D patients from } 2 \text { inner } \\
\text { city hospitals in London. } \\
\mathrm{N}=124(\mathrm{I}=65, \mathrm{C}-59) \\
\text { Mean Age }=59.8 \text { years }\end{array}$ & $\begin{array}{l}\text { I: A group-based structured Diabetes } \\
\text { Self-management programme (DSMP) } \\
\text { facilitated by diabetes specialist nurses } \\
\text { and dieticians. Followed up for a total of } \\
18 \text { weeks with assessments at baseline } \\
\text { ( } 0 \text { weeks), immediately } \\
\text { post-intervention ( } 6 \text { weeks), and } 3 \\
\text { months follow-up ( } 18 \text { weeks). } \\
\text { C: Delayed intervention. }\end{array}$ & $\begin{array}{l}\text { The main clinical outcome } \\
\text { HbA1c, which was measured at } \\
\text { baseline and } 3 \text { months. }\end{array}$ & $\begin{array}{l}\text { There was greater reduction in HBAlc at } 3 \text { months compared to baseline } \\
\text { in the intervention group compared with control. However, the difference } \\
\text { between the } 2 \text { groups was not statistically significant. } \\
\text { There was however a significant impact of dietary behaviours, exercise } \\
\text { and SMBG etc. } \\
\text { Conclusion: } \\
\text { DSMP showed significant improvement relative to controls on self- } \\
\text { management behaviours, quality of life and illness beliefs and a trend } \\
\text { towards improved HbAlc. }\end{array}$ \\
\hline $19^{40}$ & $\begin{array}{l}\text { Sarkadi A. } \\
\text { Sweden } \\
2003\end{array}$ & $\begin{array}{l}\text { Self-referred persons with } \\
\text { Type } 2 \text { diabetes } \\
\mathrm{N}=77(\mathrm{I}=39, \mathrm{C}=38) \\
\text { Mean Age } 66.5 \text { years }\end{array}$ & $\begin{array}{l}\text { I: A } 12 \text {-month long group experienced- } \\
\text { based educational program led by } \\
\text { specially trained pharmacists, assisted } \\
\text { by a diabetes nurse specialist on the first } \\
\text { two occasions. Follow up period } 24 \\
\text { months from baseline. } \\
\text { C: } 2 \text {-year waiting list. }\end{array}$ & $\begin{array}{l}\text { Main outcome was HbA1c at } 6 \text {, } \\
12 \text {, and } 24 \text { months and a } \\
\text { questionnaire was administered at } \\
\text { baseline and final follow-up. }\end{array}$ & $\begin{array}{l}\text { Intervention programme significantly decreased } \mathrm{HbA} 1 \mathrm{c} \text { by } 0.4 \% \text { at } 24 \\
\text { months after baseline }(\mathrm{P}=0.008) \text {. There was a significant drop but a } \\
\text { worsening at } 6 \text { and } 12 \text { months respectively. } \\
\text { Conclusion: } \\
\text { Experience-based group education was effective in decreasing } \\
\text { participants' HbA1c } 1 \text {-year after completed intervention. Early effect of } \\
\text { the intervention was followed by relapse after } 12 \text { months and a new, } \\
\text { significant decrease at } 24 \text { months. }\end{array}$ \\
\hline $20^{41}$ & $\begin{array}{l}\text { Thom DH } \\
\text { USA }\end{array}$ & $\begin{array}{l}\text { Low income patients } \\
\text { recruited from } 6 \text { public health } \\
\text { clinics in San Francisco with } \\
\text { HbA1C level }<8.5 \% \text { in the } \\
\text { past } 6 \text { months, } \\
\mathrm{N}=299 \text { (I=148, C=151) } \\
\text { Mean Age }=55 \text { ( } 29-82 \text { years) }\end{array}$ & $\begin{array}{l}\text { I: Coaching sessions were during clinic } \\
\text { visit or by telephone outside the clinic; } \\
\text { target goals for coaching sessions were } \\
\text { telephone contact at least twice a month } \\
\text { and } 2 \text { or more in-person contacts over } 6 \\
\text { months. } \\
\text { C: Usual care: delayed intervention. }\end{array}$ & $\begin{array}{l}\text { The primary outcome was the } \\
\text { difference in change in HbA1C } \\
\text { levels at } 6 \text { months. }\end{array}$ & $\begin{array}{l}\text { At } 6 \text { months, HbA1C levels decreased by } 1.07 \% \text { in the coached } \\
\text { group and } 0.3 \% \text { in the usual care group (difference of } 0.77 \% ;(P=.01 \text {, } \\
\text { adjusted). } \\
\text { Conclusions: } \\
\text { Peer health coaching significantly improved diabetes control in this } \\
\text { group of low-income primary care patients. }\end{array}$ \\
\hline
\end{tabular}




\begin{tabular}{|c|c|c|c|c|c|}
\hline $\begin{array}{l}\text { Study } \\
\text { No } \\
\text { (Ref) }\end{array}$ & $\begin{array}{l}\text { First Author, } \\
\text { Country, } \\
\text { Year of } \\
\text { publication }\end{array}$ & $\begin{array}{l}\text { Participants characteristics, } \\
\text { Sample size (N), } \\
\text { Mean Age }\end{array}$ & $\begin{array}{l}\text { Intervention (I) /Control (C) methods, } \\
\text { Follow up and Duration of study }\end{array}$ & Outcome measure & Outcomes/Conclusions \\
\hline $21^{42}$ & $\begin{array}{l}\text { Mollaoğlu M. } \\
\text { Turkey } \\
2007\end{array}$ & $\begin{array}{l}\text { T2D patients who were } \\
\text { discharged from the hospital } \\
\text { to go home. } \\
\mathrm{N}=50(\mathrm{I}=25, \mathrm{C}=25) \\
\text { Mean } \mathrm{Age}=52.5 \text { years }\end{array}$ & $\begin{array}{l}\text { I: Educational program consisted of } \\
\text { three } 40 \text { minutes sessions delivered by } \\
\text { nurse educators and three home visits of } \\
30 \text { minutes each; intervention occurred } \\
\text { within } 8 \text { weeks after discharge from } \\
\text { hospital, PLUS diabetes education } \\
\text { brochure. } \\
\text { C: Usual care: delayed intervention. }\end{array}$ & $\begin{array}{l}\text { The main outcome was to assess } \\
\text { the impact education on } \\
\text { metabolic profile: HbA1c, FBS, } \\
\text { post-prandial glucose, urine } \\
\text { glucose and lipid profile at the } \\
\text { end of } 8 \text { weeks. }\end{array}$ & $\begin{array}{l}\text { HbA1c significantly decreased by } 2 \% \text { in the experimental group } \\
\text { compared with controls of } 0.1 \%(\mathrm{p}<0.05) \text {. There were also significant } \\
\text { drop in FBS, post-prandial glucose and lipid profile in favour of the } \\
\text { experimental group. } \\
\text { Conclusion: regular and repetitive education provided by the } \\
\text { nurses had a positive effect on the metabolic values of persons with DM. }\end{array}$ \\
\hline $22^{43}$ & $\begin{array}{l}\text { Telle-Hjellset } \\
\text { V. } \\
\text { Norway } \\
2013\end{array}$ & $\begin{array}{l}\text { T2D Pakistani immigrant } \\
\text { women in Oslo, Norway } \\
\mathrm{N}=198(\mathrm{I}=97, \mathrm{C}=101) \\
\begin{array}{l}\text { Mean age }=41.5(25-62 \\
\text { years })\end{array}\end{array}$ & $\begin{array}{l}\text { I: used empowerment approach } \\
\text { comprising of six educational sessions } \\
\text { of } 2 \text { hours each over a } 7 \text { months period. } \\
\text { C: feedback on blood sugar levels, and } \\
\text { received lifestyle advice in one single } \\
\text { (short version) group session after the } \\
\text { follow-up tests. }\end{array}$ & $\begin{array}{l}\text { Primary outcome variables were } \\
\text { fasting and } 2 \mathrm{~h} \text { blood glucose. } \\
\text { Secondary outcomes were fasting } \\
\text { and } 2 \mathrm{~h} \text { plasma insulin and C- } \\
\text { peptide, and fasting serum lipids } \\
\text { (HDL-cholesterol and TAG), } \\
\text { HbAlc, blood pressure, waist } \\
\text { circumference and BMI. }\end{array}$ & $\begin{array}{l}\text { Mean FBS decreased by } 0 \cdot 16 \mathrm{mmol} / \mathrm{l}(95 \% \mathrm{CI} 20 \cdot 27,20 \cdot 05) \text { in the } \\
\text { intervention group, and remained unchanged in the control group } \\
\text { (difference between the groups, } \mathrm{P}=0 \cdot 022) \text {. Glucose concentration } 2 \mathrm{~h} \\
\text { after the oral glucose tolerance test decreased by } 0 \cdot 53(95 \% \mathrm{CI} 20 \cdot 84 \text {, } \\
20 \cdot 21) \mathrm{mmol} / 1 \text { in the intervention group, but not significantly more than } \\
\text { in the control group. } \\
\text { Conclusion: } \\
\text { Culturally adapted education programme may improve risk factors for } \\
\text { Type } 2 \text { diabetes in Pakistani immigrant women. }\end{array}$ \\
\hline $23^{27}$ & $\begin{array}{l}\text { Goudswaard } \\
\text { NA. } \\
\text { Netherlands } \\
2004\end{array}$ & $\begin{array}{l}\text { I: T2D patients from primary } \\
\text { care in Utrecht on maximal } \\
\text { dosages of oral } \\
\text { hypoglycaemic agents, } \\
\text { needing to start insulin } \\
(\mathrm{HbAlc}>7.0 \%) \\
\mathrm{N}=54(\mathrm{I}=25, \mathrm{C}=29) \\
\text { Mean Age }=(39-75 \text { years })\end{array}$ & $\begin{array}{l}\text { I: 6-month a collaborative, 'mixed' } \\
\text { education provided by two skilled } \\
\text { diabetes nurses in one-to-one fashion. } \\
\text { Total of six sessions, } 3-6 \text { weeks apart } \\
\text { each lasting up to } 45 \text { minutes. } \\
\text { U: Usual care }\end{array}$ & $\begin{array}{l}\text { Main outcome measures were } \\
\text { HbAlc, number of patients with } \\
\text { HbA1c }<7.0 \% \text {, and number of } \\
\text { patients treated with insulin } 18 \\
\text { months after baseline. }\end{array}$ & $\begin{array}{l}\text { At } 6 \text { weeks post intervention, HbAlc improved } 0.7 \%(95 \% \text {, CI- } 0.1,1.4) \\
\text { more in the control group; and } 60 \% \text { reached HbAlc }<7.0 \% \text { compared } \\
\text { with } 17 \% \text { in } \mathrm{UC}(P<0.01) \text {. } \\
\text { However, at } 18 \text { months there were no significant differences for HbAlc, } \\
\text { number of patients with } \mathrm{HbAlc}<7.0 \% \text {, or number treated with insulin. } \\
\text { Conclusion: } \\
\text { Education was effective in improving glycaemic control and in delaying } \\
\text { the need for insulin therapy in patients treated with maximal oral } \\
\text { hypoglycaemic therapy in the short term but not up to } 18 \text { months after } \\
\text { intervention. }\end{array}$ \\
\hline $24^{69}$ & $\begin{array}{l}\text { Adolfsson } \\
\text { ETN } \\
\text { Sweden } \\
2006\end{array}$ & $\begin{array}{l}\text { T2D patients from } 7 \text { primary } \\
\text { care centres in central } \\
\text { Sweden with HbA1c } 6-10 \% \\
\text { and diabetes duration }>1 \text { year } \\
\text { Mean } A g e=62.4 \text { years } \\
N=101(I=50, C=51)\end{array}$ & $\begin{array}{l}\text { I: } 4-5 \text { education sessions with } 1 \text { follow } \\
\text { up delivered with total contact time of } \\
2.5 \text { hours over } 7 \text { months. One year } \\
\text { follow up. } \\
\text { C: Usual care }\end{array}$ & $\begin{array}{l}\text { Impact of empowerment group } \\
\text { education on self-efficacy, } \\
\text { satisfaction with } \\
\text { daily life, BMI and HbAlc at } 1 \\
\text { year follow up compared to } \\
\text { baseline. }\end{array}$ & $\begin{array}{l}\text { At 1-year follow-up, the level of confidence in diabetes knowledge was } \\
\text { significantly higher in the intervention group than in the control group (p } \\
<0.05) \text {. No significant differences were found in other outcome } \\
\text { measures. } \\
\text { Conclusion: } \\
\text { The empowerment group education did improve patients' confidence in } \\
\text { diabetes knowledge with maintained glycaemic control despite the } \\
\text { progressive nature of the disease. }\end{array}$ \\
\hline
\end{tabular}




\begin{tabular}{|c|c|c|c|c|c|}
\hline $\begin{array}{l}\text { Study } \\
\text { No } \\
\text { (Ref) }\end{array}$ & $\begin{array}{l}\text { First Author, } \\
\text { Country, } \\
\text { Year of } \\
\text { publication }\end{array}$ & $\begin{array}{l}\text { Participants characteristics, } \\
\text { Sample size (N), } \\
\text { Mean Age }\end{array}$ & $\begin{array}{l}\text { Intervention (I) /Control (C) methods, } \\
\text { Follow up and Duration of study }\end{array}$ & Outcome measure & Outcomes/Conclusions \\
\hline $25^{44}$ & $\begin{array}{l}\text { Lujan J. } \\
\text { USA } \\
2007\end{array}$ & $\begin{array}{l}\text { Mexican Americans with } \\
\text { type } 2 \text { diabetes living in a } \\
\text { major city faith-based clinic } \\
\text { on the Texas-Mexico border } \\
\mathrm{N}=149(\mathrm{I}=75, \mathrm{C}=74) \\
\text { Mean age }=58 \text { years }\end{array}$ & $\begin{array}{l}\text { I: } 8 \text { weekly culturally specific group } \\
\text { education lasting up to } 2 \text { hrs each, } \\
\text { telephone contact, and follow-up using } \\
\text { inspirational faith based health } \\
\text { behaviour change postcards delivered by } \\
\text { community lay workers. } \\
\text { C: Usual care. }\end{array}$ & $\begin{array}{l}\text { A1C levels, diabetes knowledge, } \\
\text { and diabetes health beliefs were } \\
\text { measured } 3 \text { and } 6 \text { months post } \\
\text { baseline. }\end{array}$ & $\begin{array}{l}\text { 3-month assessment: no significant changes } \\
\text { 6-month assessment: mean change of the } \mathrm{A} 1 \mathrm{C} \text { levels, } F(1,148)=10.28 \text {, } \\
P<.001 \text {, and the diabetes knowledge scores, } F(1,148)=9.0, P<.002 \text {, of } \\
\text { the intervention group improved significantly adjusting for health } \\
\text { insurance coverage. } \\
\text { Conclusion: } \\
\text { The intervention resulted in decreased A1C levels }\end{array}$ \\
\hline $26^{70}$ & $\begin{array}{l}\text { Sturt J.A. } \\
\text { UK } \\
2008\end{array}$ & $\begin{array}{l}\text { Patients from deprived } \\
\text { communities in } 48 \text { urban } \\
\text { general practices in the West } \\
\text { Midlands, UK, with Alc }> \\
7 \% \\
\mathrm{~N}=245(\mathrm{I}=114, \mathrm{C}=131) \\
\text { Mean age }=62 \text { years }\end{array}$ & $\begin{array}{l}\text { I: Structured education derived from the } \\
\text { Diabetes Manual delivered 1:1 by } \\
\text { practice nurses with Nurse telephone } \\
\text { support was provided in weeks } 1,5 \text { and } \\
\text { 11. Follow up for } 26 \text { weeks. } \\
\text { C: 6-month delayed-intervention }\end{array}$ & $\begin{array}{l}\text { Outcomes were } \\
\text { HbA1c, cardiovascular risk } \\
\text { factors, diabetes-related distress } \\
\text { assessed at baseline and } 26 \\
\text { weeks. }\end{array}$ & $\begin{array}{l}\text { There was no significant difference in } \mathrm{HbA} 1 \mathrm{c} \text { between the intervention } \\
\text { group and the control group [difference }-0.08 \%, 95 \% \text { confidence interval } \\
\text { (CI) - } 0.28,0.11, \mathrm{p}=0.39 \text { ]. Diabetes-related distress scores were lower in } \\
\text { the intervention group compared with the control group (difference }-4.5 \text {, } \\
95 \% \mathrm{CI}-8.1,-1.0 \text { ). } \\
\text { Conclusion: } \\
\text { Diabetes Manual achieved a small improvement in patient diabetes- } \\
\text { related distress and confidence to self-care over } 26 \text { weeks, without a } \\
\text { change in glycaemic control. }\end{array}$ \\
\hline $27^{45}$ & $\begin{array}{l}\text { Fokkens A.S. } \\
\text { Netherlands } \\
2010\end{array}$ & $\begin{array}{l}\text { T2D patients GP practices } \\
\text { from the north of Netherlands } \\
\mathrm{N}=733(\mathrm{I}=581, \mathrm{C}=152) \\
\text { Mean age } 65 \text { years }\end{array}$ & $\begin{array}{l}\text { I } \\
\text { : A Structured care component delivered } \\
\text { by a general practitioner, diabetes } \\
\text { specialized nurse, practice nurse and } \\
\text { dietician. } \\
\text { C: Usual care, delayed intervention. }\end{array}$ & $\begin{array}{l}\text { Clinical outcomes of HbAlc, } \\
\text { blood pressure, cholesterol, } \\
\text { creatinine and body mass index, } \\
\text { at baseline and after } 1 \text { year. The } \\
\text { long-term effects were } \\
\text { determined after another } 2 \text { years. }\end{array}$ & $\begin{array}{l}\text { After adjustments for baseline values and duration of diabetes, the change } \\
\text { in HbA1c remained significant }(\mathrm{p}<0.05) \text { at } 1 \text { and } 3 \text { year follow up } \\
\text { compared to baseline. } \\
\text { Conclusions: } \\
\text { Structured diabetes care with multiple components has a positive } \\
\text { effect on clinical outcomes compared with care-as-usual. }\end{array}$ \\
\hline $288^{46}$ & $\begin{array}{l}\text { Davis R.M. } \\
\text { USA }\end{array}$ & $\begin{array}{l}\text { T2D patients with } \mathrm{HbA1c}> \\
7 \% \text { recruited from a federally } \\
\text { Qualified } 3 \text { health centre } \\
\text { (FQHC) in rural South } \\
\text { Carolina } \\
\mathrm{N}=165(\mathrm{I}=85, \mathrm{C}=80) \\
\text { Mean } \mathrm{Age}=59.6\end{array}$ & $\begin{array}{l}\text { I: } 12 \text {-month, 13-session curriculum } \\
\text { delivered using tele-health strategies } \\
\text { administered by a dietician and } \\
\text { nurse/certified diabetes educator (CDE). } \\
\text { C: Usual care-one 20-min diabetes } \\
\text { education session, using ADA materials, } \\
\text { conducted individually at } \\
\text { randomization. }\end{array}$ & $\begin{array}{l}\text { Primary outcome was change in } \\
\text { HbA1c, secondary, change in } \\
\text { LDL and blood pressure all } \\
\text { assessed at baseline, } 6 \text { and } 12 \\
\text { months }\end{array}$ & $\begin{array}{l}\text { A significant reduction in glycated haemoglobin in the Diabetes TeleCare } \\
\text { group from baseline to } 6 \text { and } 12 \text { months }(9.4 \pm 0.3,8.3 \pm 0.3 \text {, and } 8.2 \pm \\
0.4 \text {, respectively) compared with usual care }(8.8 \pm 0.3,8.6 \pm 0.3 \text {, and } 8.6 \\
\pm 0.3 \text {, respectively); adjusted p-values for mean differences at } 6 \text { and } 12 \\
\text { months are } p=0,003 \text { and } p=0.004 \text { respectively } \\
\text { Conclusion: } \\
\text { Telehealth effectively improved metabolic control and reduced } \\
\text { cardiovascular risk in an ethnically diverse and rural population }\end{array}$ \\
\hline
\end{tabular}




\begin{tabular}{|c|c|c|c|c|c|}
\hline $\begin{array}{l}\text { Study } \\
\text { No } \\
\text { (Ref) }\end{array}$ & $\begin{array}{l}\text { First Author, } \\
\text { Country, } \\
\text { Year of } \\
\text { publication }\end{array}$ & $\begin{array}{l}\text { Participants characteristics, } \\
\text { Sample size (N), } \\
\text { Mean Age }\end{array}$ & $\begin{array}{l}\text { Intervention (I) /Control (C) methods, } \\
\text { Follow up and Duration of study }\end{array}$ & Outcome measure & Outcomes/Conclusions \\
\hline $29^{71}$ & $\begin{array}{l}\text { Sönnichsen } \\
\text { A.C. } \\
\text { Austria } \\
2010\end{array}$ & $\begin{array}{l}\text { T2D patients from GP } \\
\text { practices from Salzburg, } \\
\text { Austria } \\
\mathrm{N}=1489(\mathrm{I}=649, \mathrm{C}=840) \\
\text { Mean age }=65.5 \text { years }\end{array}$ & $\begin{array}{l}\text { I: Nine hours of structured patient- } \\
\text { education in } 4 \text { modules with a group } \\
\text { size of } 3 \text { to } 12 \text { patients. } 3 \text { monthly } \\
\text { follow up over } 12 \text { months } \\
\text { C: Usual care }\end{array}$ & $\begin{array}{l}\text { Primary outcome measure was a } \\
\text { change in } \mathrm{HbA} 1 \mathrm{c} \text { after one year. }\end{array}$ & $\begin{array}{l}\text { Significance was lost in mixed models adjusted for baseline value and } \\
\text { cluster-effects (adjusted mean difference }-0.03 \text { ( } 95 \% \text { CI }-0.15 ; 0.09, \mathrm{p}= \\
0.607) \text {. } \\
\text { Conclusion: } \\
\text { The Austrian DMP improves process quality and enhances weight } \\
\text { reduction, but does not significantly improve metabolic control for T2D } \\
\text { patients }\end{array}$ \\
\hline $30{ }^{47}$ & $\begin{array}{l}\text { Trouilloud D. } \\
\text { France } \\
2013\end{array}$ & $\begin{array}{l}\text { Physician confirmed T2D } \\
\text { from a French hospital with } \\
\text { average diabetes duration of } \\
>10 \text { years } \\
\mathrm{N}=120 \\
\text { Mean age }=56.7 \text { years }\end{array}$ & $\begin{array}{l}\text { I: 3-day programme by multi- } \\
\text { professional team including eight group } \\
\text { sessions, each session lasting } 2-3 \text { hours. } \\
\text { Sessions were interactive and patient- } \\
\text { centred, and consisted of both } \\
\text { educational and problem-solving } \\
\text { activities. Follow up was } 3 \text { months. } \\
\text { C: Usual care waiting list. }\end{array}$ & $\begin{array}{l}\text { Assess impact of Therapeutic } \\
\text { education (TPE) on self- } \\
\text { management behaviours, } \\
\text { perceived competence and } \\
\text { HbA1c at } 3 \text { months compared to } \\
\text { baseline. }\end{array}$ & $\begin{array}{l}\text { Follow-up Scheffe comparisons showed that HbA1c significantly } \\
\text { decreased in the TPE group }(p<0.001) \text {, whereas it remained stable in the } \\
\text { control group }(p=0.55) \text {. } \\
\text { Conclusion: } \\
\text { The education programme resulted in positive changes in glycaemic } \\
\text { control and self-management behaviours after three months follow-up. }\end{array}$ \\
\hline $31^{14}$ & $\begin{array}{l}\text { Deakin T.A. } \\
\text { UK } \\
2006\end{array}$ & $\begin{array}{l}\text { T2D from GP practices from } \\
\text { Lancashire, UK } \\
\mathrm{N}=314 \text { ( } \mathrm{I}=157, \mathrm{C}=157) \\
\text { Mean age }=61.5 \text { ( } 30-80 \text { years) }\end{array}$ & $\begin{array}{l}\text { I: Six 2-h weekly group sessions of } \\
\text { structured self-management education } \\
P L U S \text { Diabetes manual delivered by } \\
\text { diabetes educators. Follow up to } 14 \\
\text { months. } \\
\text { C: Usual care PLUS diabetes education } \\
\text { and review with prearranged individual } \\
\text { appointments. }\end{array}$ & $\begin{array}{l}\text { Primary outcome was change in } \\
\text { HbA1c at baseline and } 14 \\
\text { months. }\end{array}$ & $\begin{array}{l}\text { The intervention (X-PERT) group compared with the control group } \\
\text { showed significant improvements in the mean HbA1c ( }-0.6 \% \text { vs. }+0.1 \% \text {, } \\
\text { repeated measures ANOVA, } P<0.001) \text {. } \\
\text { Conclusion: } \\
\text { Participation in the X-PERT Programme by adults with Type } 2 \\
\text { diabetes was shown at } 14 \text { months to have led to improved glycaemic } \\
\text { control }\end{array}$ \\
\hline $32{ }^{29}$ & $\begin{array}{l}\text { Guo X.H. } \\
\text { China } \\
2014\end{array}$ & $\begin{array}{l}\text { Insulin-treated T2DM } \\
\text { patients on } 2 \text { or more oral } \\
\text { anti-diabetic drugs and } \\
\text { HbA1c }>7.5 \% \text { for }>3 \text { months } \\
\mathrm{N}=1511 \\
\text { Age }=57.1 \text { years }\end{array}$ & $\begin{array}{l}\text { I: Structured diabetes education, } \\
\text { including } 8 \text { models and } 3 \text { telephone } \\
\text { follow-ups (delivered by trained nurses) } \\
\text { plus insulin therapy. Follow up was } 16 \\
\text { weeks. } \\
\text { C: Usual care plus insulin therapy. } \\
\text { All of them discontinued OADs except } \\
\text { biguanides and } \alpha \text {-glucosidase inhibitors. }\end{array}$ & $\begin{array}{l}\text { Primary endpoint was the change } \\
\text { in HbA1c from baseline at } 16 \\
\text { weeks. }\end{array}$ & $\begin{array}{l}\text { Significant reductions in } \mathrm{HbA} 1 \mathrm{c} \text { from baseline in the education group } \\
\text { compared with controls }(2.16 \% \text { vs. } 2.08 \% ; P<0.05) \text {. } \\
\text { Improvement in Morisky Medication Adherence Scale was greater in the } \\
\text { education group }(P<0.05) \text {. } \\
\text { No difference in overall incidence of hypoglycaemic events in the two } \\
\text { groups (education and control groups was } 2.28 \text { and } 1.75 \text { episodes per } \\
\text { person-year, respectively }(P>0.05) \text {. } \\
\text { Conclusion: } \\
\text { Structured education can promote the ability of patients to self-manage } \\
\text { and their compliance with medications, thereby achieving better } \\
\text { outcomes }\end{array}$ \\
\hline
\end{tabular}




\begin{tabular}{|c|c|c|c|c|c|}
\hline $\begin{array}{l}\text { Study } \\
\text { No } \\
\text { (Ref) }\end{array}$ & $\begin{array}{l}\text { First Author, } \\
\text { Country, } \\
\text { Year of } \\
\text { publication }\end{array}$ & $\begin{array}{l}\text { Participants characteristics, } \\
\text { Sample size (N), } \\
\text { Mean Age }\end{array}$ & $\begin{array}{l}\text { Intervention (I) /Control (C) methods, } \\
\text { Follow up and Duration of study }\end{array}$ & Outcome measure & Outcomes/Conclusions \\
\hline $33^{30}$ & $\begin{array}{l}\text { Kim S. } \\
\text { South Korea } \\
2008\end{array}$ & $\begin{array}{l}\text { Obese type } 2 \\
\text { Diabetes patients } \\
\mathrm{N}=34(\mathrm{I}=18, \mathrm{C}=16) \\
\text { Mean Age } 47.0=(\mathrm{I}=48.5 \\
\mathrm{C}=45.5)\end{array}$ & $\begin{array}{l}\text { I: SMS (by personal cellular phone) and } \\
\text { internet (phone and computer based) } \\
\text { intervention PLUS } 4 \text { meetings with } \\
\text { endocrinologist. Follow up was } 3 \\
\text { monthly for } 1 \text { year. } \\
\text { C: Usual care PLUS } 4 \text { meetings with } \\
\text { endocrinologist. }\end{array}$ & $\begin{array}{l}\text { Primary end point was } \% \text { change } \\
\text { in plasma glucose at } 3,6,9 \text {, and } \\
12 \text { months. }\end{array}$ & $\begin{array}{l}\text { HbA1c decreased } 1.22 \text { percentage points at } 3 \text { months, } 1.09 \text { percentage } \\
\text { points at } 6 \text { months, } 1.47 \text { percentage points at } 9 \text { months, and } 1.49 \\
\text { percentage points at } 12 \text { months compared with baseline in the } \\
\text { intervention group (all time points, } p<0.05 \text { ). The percentage change in } \\
\text { the control group was, however, not significant. } \\
\text { Conclusion: } \\
\text { This web-based intervention using SMS of personal cellular phone and } \\
\text { Internet improved HbA1c and } 2 \mathrm{HPPT} \text { at } 3,6,9 \text {, and } 12 \text { months in } \\
\text { patients with obese type } 2 \text { diabetes. }\end{array}$ \\
\hline $34^{48}$ & $\begin{array}{l}\text { Carter EL } \\
\text { USA }\end{array}$ & $\begin{array}{l}\text { Inner-city African Americans } \\
\text { with T2D } \\
\mathrm{N}=47 \text { (I=26, C=21) } \\
\text { Mean age } 50.5 \text { (36-74 years) }\end{array}$ & $\begin{array}{l}\text { I: Structured bi-weekly internet based } \\
\text { diabetes education programme by } \\
\text { diabetes nurse educators. Follow up was } \\
9 \text { months. } \\
\text { C: Usual care. }\end{array}$ & $\begin{array}{l}\text { Primary end point was A1c } \\
\text { measure of } 7 \% \text { or below during } \\
\text { the last month or longer of } \\
\text { enrolment. }\end{array}$ & $\begin{array}{l}\text { There was a significant association between participation in the } \\
\text { intervention and achieving a haemoglobin A1c measure of } 7 \% \text { or below, } \\
\text { chi squared }=5.983, p<.05 \text {. Based on the odds ratio, patients were } 4.58 \\
\text { times more likely to reach the desired haemoglobin A1c target. } \\
\text { Conclusion: The online diabetes self-management portal complemented } \\
\text { by biweekly virtual visits with a nurse enabled } 26 \text { African Americans } \\
\text { with diabetes to improve their health outcomes }\end{array}$ \\
\hline $35^{50}$ & $\begin{array}{l}\text { Graziano JA. } \\
\text { Italy } \\
2009\end{array}$ & $\begin{array}{l}\text { T2D patients with } \mathrm{HbA} 1 \mathrm{c} \\
\text { equal or greater to } 7 \% \\
\mathrm{~N}=120(\mathrm{I}=62, \mathrm{C}=58) \\
\text { Mean age }=61.5(50-90 \\
\text { years })\end{array}$ & $\begin{array}{l}\text { Automated Telephone } \\
\text { Intervention consisting of daily, } \\
\text { automated pre-recorded voice message } \\
\text { relaying a short (less than } 1 \text { minute) } \\
\text { message related to type } 2 \text { DM. Follow } \\
\text { up period was for } 9 \text { months. } \\
\text { C: Usual care, } 2-3 \text { monthly visits. }\end{array}$ & $\begin{array}{l}\text { Primary end point was impact of } \\
\text { intervention on } \mathrm{HbA} 1 \mathrm{c} \text { at } 9 \\
\text { months. }\end{array}$ & $\begin{array}{l}\text { Adjusted mean changes in the intervention and control groups were - } \\
1.13 \% \text { and }-1.10 \% \text { respectively, with no significant difference between } \\
\text { the two ( } \mathrm{p}=0.89) \text {. } \\
\text { Conclusion: } \\
\text { No overall treatment effect was seen on change in HbAlc level. }\end{array}$ \\
\hline $36^{31}$ & $\begin{array}{l}\text { Trento M. } \\
\text { Italy } \\
2010\end{array}$ & $\begin{array}{l}\text { Non-insulin-treated T2D } \\
\text { patients aged } 80 \text { years with } \\
>1 \text { year diabetes duration } \\
\text { known diabetes duration } \\
\mathrm{N}=815(\mathrm{I}=421, \mathrm{C}=394) \\
\text { Mean age }=69.3 \text { years }\end{array}$ & $\begin{array}{l}\text { I: Seven 1-h sessions were held over } 2 \\
\text { years and repeated. Education } \\
\text { (ROMEO) involved mainly group work, } \\
\text { hands-on activities, problem solving, } \\
\text { real-life simulations, and role-playing. } \\
\text { Total follow up was } 4 \text { years. } \\
\text { C: Routine individual visits (Usual care) }\end{array}$ & $\begin{array}{l}\text { Primary outcomes include } \\
\text { cognitive, psychological and } \\
\text { metabolic impact including } \\
\text { glycaemic control. }\end{array}$ & $\begin{array}{l}\text { At study end there was lower A1C ( }(7.3 \pm 0.9 \text { vs. } 8.8 \pm 1.2 \%) \text { with an } \\
\text { adjusted mean difference of }-1.49 \text { (CI, }-1.63,-1.34), p<0.001 \text {; and } \\
\text { improvements in other psychological and metabolic parameters. } \\
\text { Conclusion: } \\
\text { ROMEO, a multicentre controlled trial, showed that group care is } \\
\text { transferable and confirmed its efficacy. }\end{array}$ \\
\hline
\end{tabular}


APPENDIX 2: Summary of studies on Effects of Structured Education on Hypoglycaemia in Type 2 Diabetes

\begin{tabular}{|c|c|c|c|c|c|}
\hline $\begin{array}{l}\text { Study } \\
\text { No (Ref) }\end{array}$ & $\begin{array}{l}\text { First Author, } \\
\text { Country, } \\
\text { Year of } \\
\text { publication }\end{array}$ & $\begin{array}{l}\text { Participants characteristics, } \\
\text { Sample size (N), } \\
\text { Mean Age }\end{array}$ & $\begin{array}{l}\text { Intervention (I) /Control (C) methods, } \\
\text { Follow up and Duration of study }\end{array}$ & Outcome measure & Outcomes/Conclusions \\
\hline $1^{28}$ & $\begin{array}{l}\text { Lorig K. } \\
\text { USA } \\
2009\end{array}$ & $\begin{array}{l}\text { Type } 2 \text { diabetes patients from } \\
\text { churches and senior centres } \\
\mathrm{N}=345 \text { (I=186, C: } 159) \\
\text { Mean age }=66.7 \text { ( } 24-93 \text { years) }\end{array}$ & $\begin{array}{l}\text { I: } 6 \text {-week community-based, peer-led } \\
\text { diabetes self-management program } \\
\text { (DSMP) consisting of } 2^{1 / 2} \text { hours weekly by } \\
2 \text { peer leaders. Class sizes ranged from } 10 \\
\text { to } 15 \text {. } \\
\text { After } 6 \text { months Intervention group had } \\
\text { additional } 6 \text { months of longitudinal follow } \\
\text { up. } \\
\text { C: Usual care, but offered DSMP after } 6 \\
\text { months }\end{array}$ & $\begin{array}{l}\text { A1C and body mass index } \\
\text { were measured at baseline, } \\
6 \text { months, and } 12 \text { months. } \\
\text { All other data were } \\
\text { collected by self- } \\
\text { administered } \\
\text { questionnaires. }\end{array}$ & $\begin{array}{l}\text { At } 6 \text { months, DSMP participants did not demonstrate significant } \\
\text { improvements in A1C as compared with controls ( }>0.05) \\
\text { Also there were significant improvements in symptoms of } \\
\text { hypoglycaemia, depression, communication with physicians, healthy } \\
\text { eating, and reading food labels at } 6 \text { months }(P<0.01 \\
\text { Conclusions: } \\
\text { A community-based, peer led diabetes programme for people with } \\
\text { diabetes without elevated A1C resulted in benefits including } \\
\text { significantly less hypoglycaemia but not in glycaemic control. }\end{array}$ \\
\hline $2^{29}$ & $\begin{array}{l}\text { Guo X.H. } \\
\text { China } \\
2014\end{array}$ & $\begin{array}{l}\text { Insulin-treated T2DM patients on } \\
2 \text { or more oral anti-diabetic drugs } \\
\text { and HbA1c }>7.5 \% \text { for }>3 \text { months } \\
\mathrm{N}=1511 \\
\text { Age }=57.1 \text { years }\end{array}$ & $\begin{array}{l}\text { I: Structured diabetes education, including } \\
8 \text { models and } 3 \text { telephone follow-ups } \\
\text { (delivered by trained nurses) plus insulin } \\
\text { therapy. Follow up was } 16 \text { weeks. } \\
\text { C: Usual care plus insulin therapy. } \\
\text { All of them discontinued OADs except } \\
\text { biguanides and } \alpha \text {-glucosidase inhibitors. }\end{array}$ & $\begin{array}{l}\text { Primary endpoint was the } \\
\text { change in HbAlc from } \\
\text { baseline at } 16 \text { weeks. }\end{array}$ & $\begin{array}{l}\text { Significant reductions in } \mathrm{HbAlc} \text { from baseline in the education group } \\
\text { compared with controls }(2.16 \% \text { vs. } 2.08 \% ; P<0.05) \text {. } \\
\text { Improvement in Morisky Medication Adherence Scale was greater in } \\
\text { the education group }(P<0.05) \text {. } \\
\text { No difference in overall incidence of hypoglycaemic events in the two } \\
\text { groups (education and control groups was } 2.28 \text { and } 1.75 \text { episodes per } \\
\text { person-year, respectively ( } P>0.05) \text {. } \\
\text { Conclusion: } \\
\text { Structured education can promote the ability of patients to self-manage } \\
\text { and their compliance with medications, thereby achieving better } \\
\text { outcomes. There was no difference in overall incidence of } \\
\text { hypoglycaemic. }\end{array}$ \\
\hline
\end{tabular}

